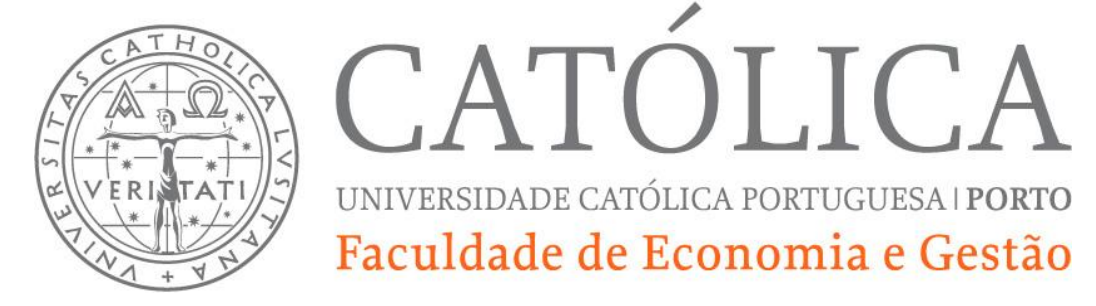
FINANCIAL CRISIS

\author{
João Pinto \\ Universidade Católica Portuguesa (Porto) \\ Mário Santos \\ Universidade Católica Portuguesa (Lisboa)
}




\title{
CORPORATE FINANCING CHOICES AFTER THE 2007-2008 FINANCIAL CRISIS
}

\author{
João M. Pinto \\ Catholic University of Portugal \\ e-mail: jpinto@porto.ucp.pt \\ Mário C. Santos \\ Catholic University of Portugal \\ e-mail: $\underline{\text { msantos@ porto.ucp.pt }}$
}

First version: December 2013

This version: April 2014

Please do not quote without permission

\begin{abstract}
We study the factors that, arguably, affect the probability of a new borrower choosing between structured finance (SF), either project finance (PF) loans or asset securitization (AS) bonds, and straight debt finance (SDF) - corporate bonds (CB) - transactions using a large cross section of 24,435 Western European loans and bonds issued between January $1^{\text {st }}, 2000$ and December $31^{\text {st }}, 2011$.

Borrowers chose an SF transaction when they seek long-term financing and when they operate in a country with lower sovereign rating. Findings suggest that industrials, utilities, transportation, and governmental borrowers exhibit a higher likelihood of an SF transaction, more specifically, a PF transaction. Several macroeconomic factors, like market interest rate levels and volatility, and the slope of the Euro swap curve, positively influence the probability of observing an SF over an SDF transaction. The 2007-2008 financial crisis and the subsequent European sovereign debt crisis decrease the probability of observing an AS transaction. During the crisis, macroeconomic factors seem to significantly influence the probability of a sponsor to choose SF over SDF.

We also find that credit spreads and loan to value ratios have a significant negative relationship for AS bonds. Overall, findings are in line with security design literature. SF transactions or instruments, based on extensively contractual and security design, allow the reduction of the net costs associated with asymmetric information and agency conflicts.
\end{abstract}




\title{
CORPORATE FINANCING CHOICES AFTER THE 2007-2008 FINANCIAL CRISIS*
}

\begin{abstract}
We study the factors that, arguably, affect the probability of a new borrower choosing between structured finance (SF), either project finance (PF) loans or asset securitization (AS) bonds, and straight debt finance (SDF) - corporate bonds (CB) - transactions using a large cross section of 24,435 Western European loans and bonds issued between January 1st, 2000 and December 31st, 2011.

Borrowers chose an SF transaction when they seek long-term financing and when they operate in a country with lower sovereign rating. Findings suggest that industrials, utilities, transportation, and governmental borrowers exhibit a higher likelihood of an SF transaction, more specifically, a PF transaction. Several macroeconomic factors, like market interest rate levels and volatility, and the slope of the Euro swap curve, positively influence the probability of observing an SF over an SDF transaction. The 2007-2008 financial crisis and the subsequent European sovereign debt crisis decrease the probability of observing an AS transaction. During the crisis, macroeconomic factors seem to significantly influence the probability of a sponsor to choose SF over SDF.

We also find that credit spreads and loan to value ratios have a significant negative relationship for AS bonds. Overall, findings are in line with security design literature. SF transactions or instruments, based on extensively contractual and security design, allow the reduction of the net costs associated with asymmetric information and agency conflicts.
\end{abstract}

Key words: financing, security design, loan and bond pricing, structured finance, project finance, asset securitization, corporate bonds, financial crisis.

JEL classification: F34; G01; G12; G21; G24

* This paper is based on João Pinto's University of Porto Ph.D. dissertation. We would like to thank Álvaro Nascimento, Brian Maia-Tanner, Gordon Roberts, Jorge Alcover, João Santos, Luís Pacheco, Manuel Marques, Miguel Ferreira, Pedro Duarte Silva, Ricardo Cruz, Vitor Nascimento, and William Megginson for valuable comments on an earlier draft. We also gratefully acknowledge the helpful suggestions received from seminar participants at the 2011 FMA Doctoral Student Consortium. The user disclaimer applies concerning errors and omissions. We are especially grateful to Goldman Sachs for providing access to DCM Analytics database, and to the Catholic University of Portugal, Porto for providing access to the DealScan database. João Pinto is the corresponding author and can be reached at jpinto@porto.ucp.pt. 


\section{Introduction}

Structured finance (SF) transactions, either in the form of project finance or asset securitization structures, are financial transactions designed to meet, as closely as possible, the different requirements and needs of borrowers and investors. This paper aims to enlighten some of the main determinants of issuers selecting SF versus straight debt finance (SDF) transactions. Despite the important insightful predictions provided by security design models, firms' financing structure decisions still remain unsatisfactorily explained, mainly $(i)$ in terms of SF transactions, and (ii) with respect to the motivation for the firms to decide resorting to SF as opposed to straight debt. One possible explanation is that extant security design theories do not simultaneously and dynamically endogenize all contractual features. Finally, the suggested link between SF and the turmoil of the financial markets makes the analysis of the determinants of choosing an SF transaction versus an SDF transaction particularly interesting and relevant at both the theoretical and practical levels.

In an economy à la Modigliani and Miller's (1958), ${ }^{1}$ SF transactions would not matter. However, as argued in Miller (1988) "showing what doesn't matter can also show, by implication, what does" (emphasis in the original). Therefore, and recognizing that firms' debt and equity are, de facto, assetbacked securities, M\&M's irrelevance theorem can play a fundamental role within an SF framework. In a world of perfectly competitive, liquid and frictionless financial markets, where market participants have homogeneous expectations, tranching, ${ }^{2}$ or the act of encapsulating an initiative or a pool of assets in an $a d$ hoc organization, ${ }^{3}$ would not add value and a firm's financing structure would be irrelevant. Thus, the existence of market imperfections and frictions, including asymmetric information problems, agency conflicts, and market and contract incompleteness, can explain tranching, 'off-balance sheet financing', and the benefits of SF instruments. In this framework, structured financing may matter, because it, arguably, may create value by minimizing the net costs associated with market imperfections.

Despite the economic benefits for sponsors and investors, SF transactions may also have disadvantages, especially when used inappropriately. There is broad consensus about the non-negligible role played by SF transactions, especially asset securitizations, in the development and propagation of the 2007-2008 financial crisis, and the subsequent European sovereign debt crisis. Typically, a highly asset securitization structured instrument exhibit a superior level of aggregated informational opacity, than the

\footnotetext{
${ }^{1}$ Hereafter M\&M.

2 Tranching means the creation of multiple types of securities backed by the firm's (or by the underlying asset pool, when considering securitization) assets and is considered one of the most important features that distinguishes SF instruments from traditional debt products. See, e.g., DeMarzo (2005) for further details.

${ }^{3}$ A key feature of SF transactions, which differentiates them from other financing arrangements, is the presence of a separate vehicle company, Special Purpose Vehicle (SPV) or Special Purpose Entity (SPE), incorporated to initiate the deal, and to secure cash receipts and the resulting payments.
} 
individual assets included in the SPV's asset pool, thereby worsening informational asymmetries among market participants, and therefore increasing the severity of adverse selection and moral hazard problems.

A firm's rational value maximizer manager / owner should choose between SF or SDF financing, based on the cost of capital efficiency of the available financing alternatives. For example, the decision either to go with a project finance transaction or with an SDF, should be based on the trade-off between the composite cost of capital of the project finance and the sponsor's, and the sponsor's overall cost of capital after the SDF. Thus, one first question is raised concerning the choice between SF and SDF transactions: What factors determine the managerial choice between these financing alternatives?

The fact that firms issue securities other than debt and equity, and the recurrent introduction of new and more complex securities, raises one second question: 'What are the more efficient securities a firm should optimally issue? The paper also aims answering this question focusing on the choice between SF and SDF instruments.

To empirically trying to answer these questions, we use a comprehensive sample of SF - project finance (PF) loans and asset securitization (AS) bonds - and SDF - corporate bonds (CB) - transactions issued in Western European countries between January $1^{\text {st }}$, 2000 and December $31^{\text {st }}, 2011$. Our sample contains information about 2,859 PF tranches (worth Euro 332.1 billion), 599 AS issues (worth Euro 179.1 billion), and 20,977 CB issues (worth Euro 5,786.5 billion).We aim at determining what affects the probability of a new borrower choosing between SF and SDF transactions, and also between a PF loan and an AS bond or between an AS bond and a CB.

Looking at the estimation of the selection equation in model [1], our empirical findings indicate that: $(i)$ the effect of lower tranche size increases the probability of selecting an SF transaction, rather than an SDF transaction; (ii) borrowers chose an SF transaction when they seek long-term financing, and when they operate in a country with higher credit risk; (iii) borrowers in industrial, utilities, transportation and government areas increase the likelihood of an SF transaction, more specifically a PF transaction; (iv) the probability of observing an AS bond issue increases if the borrower belongs to the financial industry; $(v)$ the 2007-2008 financial crisis decreases the probability of observing an AS transaction; (vi) macroeconomic factors, like the level of the interest rates, market volatility, the slope of the Euro swap curve, and credit accessibility positively influence the probability of observing an SF loan or bond; and (vii) the market volatility, the slope of the Euro swap curve, and credit accessibility have proven to be irrelevant in the process of making a choice between PF loans and AS bonds.

For testing the robustness of our results, we split the sample in: $(i)$ a pre-crisis sub-sample, from January $1^{\text {st }}, 2000$ through to September $14^{\text {th }}, 2008$; and (ii) a crisis sub-sample, from September $15^{\text {th }}, 2008$ through to December $31^{\text {st }}, 2011$. Results show a statistically significant increase, of 572.93 bps, in SF's credit spreads between the two sub-sampling periods. Additionally, splitting our sample does not bias the 
main conclusions regarding microeconomic variables, in line with the results of the overall sampling period, what indicates that our results are robust in this dimension. However, robustness tests of macroeconomic factors, like the interest rate levels, the market volatility, and the Euro swap curve slope, document that the pre-crisis sub-sample results are not statistically significant.

This paper contributes to extant literature in different ways. The first, because, to the best of our knowledge, it may be the first to look at the financing choices between SF and SDF transactions. The paper contributes to 2007-2008 financial crisis, and the subsequent European sovereign debt crisis literature. The 2007-2008 financial crisis and the subsequent European sovereign debt crisis significantly impacted the choice between these two types of financing transactions. We find that credit rating is the most important pricing factor for AS bonds at issue. This fact may be a consequence of investors' extensive reliance on credit ratings because of the innate informational complexity of securitization structures. The paper also contributes to the corporate financial economics literature, by improving the understanding of what the boundaries of firms are and new insights on the industrial organization economics. The nature of the firm as a nexus of contracts is even more apparent in SF than in SDF settings. In PF and AS, a specially incorporated new firm (SPV) is created to manage all contracts and to make cash flows more readily verifiable for lenders. In such cases, it is crucial to design financial contracts with the objective of pre-committing, whenever possible, the possible behavior of the SPV management. Careful contract design prevents agency problems between SPV sponsoring firms and lenders, and establishes an effective risk management framework. Pre-committing future obligations also reduces the volatility of cash flows available for debt service.

The paper distinguishes from prior research because: $(i)$ no full-scale empirical study of the choice between SF and SDF transactions has yet been published - we overcome this gap by simultaneously using DealScan and DCM Analytics databases; (ii) in order to test the expected impact on the probability of a sponsor to choose SF over SDF we resort to a generalized Tobit model, following Heckman (1979); and (iii) the sampling period covers a pre-crisis period, from January $1^{\text {st }}, 2000$ through to September $14^{\text {th }}, 2008$, and a crisis period, from September $15^{\text {th }}, 2008$ through to December $31^{\text {st }}, 2011$.

The remaining of the paper is organized as follows. In the next section we discuss the security design theoretical and empirical background, and the interconnections with SF literature. Section 3 describes the DealScan and DCM Analytics databases used in this study. The basic characteristics of the samples of SF versus SDF transactions are also presented here. In section 4, the organization choice models are discussed and applied. The factors that influence the choice of an SF transaction instead of an SDF transaction are presented and discussed. Section 5 summarizes the paper. 


\section{Security Design and Structured Finance}

\subsection{Theoretical and Empirical Background}

The literature on security design is quite extensive. Its comprehensive survey is well beyond the scope of this work. Instead, we parsimoniously review the mainstream financial structure literature highlighting the more relevant contributions to identify the economic factors that, arguably, may underlie the origination of structured finance transactions.

It is well understood that under conditions of complete, perfect and frictionless markets, and complete contracting, the firm's financing choices are irrelevant in terms of its market value, and in terms of the welfare of its security holders $(M \& M){ }^{4}$ By implication, the specific type and features of the financing contractual arrangement are also irrelevant. Therefore, the debt or equity contracts under which investors supply funds to the firm, are optimal financial contracting arrangements. ${ }^{5}$

In real-world market economies, markets are incomplete and plagued with imperfections and frictions, and contracts are incomplete, though. ${ }^{6}$ In this environment a firm's financing policy does matter. ${ }^{7}$ However, theoretically it is still not well understood why actual real world firms' financing contracts, recurrently appear in certain patterns [e.g., Harris and Raviv (1989)]. This suggests that it is needed a more robust theoretical framework to help explaining the financing decision-making of those firms, namely in terms of security design. ${ }^{8}$

The notion that a firm can be conceptualized as a nexus of contracts is a particularly powerful and helpful framework to rationalize the corporate financial structure. ${ }^{9}$ In a nexus of contracts setting, ownership rights play a central role in analyzing contractual relationships [Grossman and Hart (1986), Stiglitz (1989), and Hart and Moore (1990)]. The specification of such individual ownership rights requires contracting the allocation of both residual rights of control, and residual rents [e.g., Milgrom and Roberts (1992)]. The importance of residual control rights derives from the difficulty of writing complete

\footnotetext{
${ }^{4}$ If a contract could be costlessly written, laying down each party's obligations and payoffs for any conceivable eventuality in every possible future state of the world, then any contracting problems would not emerge.

${ }^{5}$ M\&M irrelevance theorem was extended and generalized under less stringent assumptions, including the presence of risky debt and hybrid securities, the relaxation of the risk class assumption, and assuming intertemporal settings [see Stiglitz (1969, 1974), Smith (1972), Baron (1974, 1976), Merton (1974), and Hellwig (1981)].

${ }^{6}$ Among the problems associated with market imperfections and frictions, and contracts incompleteness are: $(i)$ the imperfect observability of agent's actions; and (ii) the costs of writing, executing, and enforcing contracts.

${ }^{7}$ As argued by Stiglitz (1989) "we cannot simultaneously hold to the view that firms are rational profit maximizing (shareholders are rational investors) and that debt-equity ratios (and financial policies more generally) are irrelevant".

${ }^{8}$ As pointed out by Allen and Gale (1988) "to develop a theory of optimal security design, it is clearly necessary to develop a framework in which markets are incomplete."

${ }^{9}$ Coase (1937) pioneered the 'nexus of contracts' framework. It received so widespread support [e.g., Alchien and Demsetz (1972), Jensen and Meckling (1976), and Milgrom and Roberts (1992)] that Bolton and Scharfstein (1998) and Allen and Winton (1995) argue that it is the dominant paradigm in modern corporate finance.
} 
contracts. ${ }^{10}$ Therefore, the uncertainty inherent to incomplete contracts is potentially a source for opportunistic behavior of the contracting parties [Bolton and Scharfstein (1998)]. ${ }^{11}$

Within this literature, Allen and Winton (1995) argue that the security design theoretical framework provides a promising foundation to examine the derivation of efficient financial contracts as mechanisms to optimally align the interests of the contracting parties.

The observation of real world firms' financing behavior shows that their financing patterns tend to vary cross-sectionally and over time, within apparently homogeneous industries, and even when markets, institutions, regulation and taxations seem apparently invariant. Despite the remarkable diversity of available financing alternatives, continued security design innovation still seems to be a prolific source of new tailor-made security arrangements and contractual designs for the corporate financing world. Structured finance instruments are commonly mentioned as one group of newly introduced instruments resulting from innovation activities in security and contractual design. ${ }^{12}$

The appeal of structured finance instruments is contingent on the trade-off between the costs for the borrower in designing and structuring a new instrument, and the benefits they offer to investors or lenders. Among the sources of value creation identified in the extant structured finance literature, are included: $(i)$ risk reallocation / yield reduction - risks are transferred from those who are less willing to bear it to those who are more willing to bear it (e.g., collateralized mortgage obligations (CMOs) and stripped mortgage-backed securities - AS); (ii) agency costs mitigation - capital structure must be engineered to accommodate the risk-return preferences of the various classes of investors lowering potential agency costs (e.g., PF and leveraged buyouts); (iii) reduced issuance costs (e.g., AS); and (iv) tax arbitrage (e.g., structured leases) [e.g., Finnerty (1988)].

\subsubsection{The Economics of Structured Finance}

Structured finance is related to the design of financial instruments based on the use of contracting tools and mechanisms to meet, as closely as possible, the requirements and needs of the originator or owner of an asset (or pool of assets) and investors' expected requirements. Thus, SF encompasses all financial arrangements helping to efficiently (re)finance a specified pool of assets beyond the scope of onbalance sheet financing [Cherubini and Della Lunga (2007), Fabozzi and Kothari (2007), and Jobst (2007)].

${ }_{10}$ Williamson (1990) argues that in a bounded rationality world "all complex contracts are unavoidably incomplete."

${ }^{11}$ According to Hart (1988), Ronald Coase and Oliver Williamson should be credited for the "insight that the firm as an institution takes on importance only in a world of incomplete contracts." See Tirole (1999), Hart and Moore (1999), Maskin and Tirole (1999), and Aghion and Bolton (1992), for rigorous discussions on incomplete contracts.

12 Finnerty (1988) suggests that leveraged buyout structuring, corporate restructuring, and project finance/lease/asset-based financial structuring are relevant examples of financial innovation. 
In an SF transaction, the requirements of the owner of the assets or cash flows refer to liquidity, funding, risk transfer, efficient risk allocation, favorable capital, tax and accounting treatment, or other needs. Instruments are usually designed, namely in terms of covenants, warrantees, corporate structure, contracts, and trusts, to achieve segregation of those assets or cash flows from the originator or sponsor of the transaction. Additionally, credit enhancement mechanisms are implemented (e.g., the use of warrantees to enhance recoveries and tranching to define risk attachment points). In brief, there are three main specificities of SF. First, the critical role played by the vehicle company; i.e., the recipient of the raised funds is a separate entity from the party or parties sponsoring the transaction, which plays an important role in the segmentation of cash flows and risks in a form proving more attractive for investors, through a structuring process. ${ }^{13}$ Secondly, the high level of leverage, and finally, the centrality of prospective cash flow in order to evaluate the feasibility of the operation.

Prior research has identified the following main categories of SF transactions: (i) asset securitization; ${ }^{14}$ (ii) project finance, ${ }^{15}$ (iii) structured leasing $;{ }^{16}$ and (iv) leveraged acquisitions, namely Leveraged Buy-Outs (LBOs) ${ }^{17}$ [Roever and Fabozzi (2003), Caselli and Gatti (2005), Davis (2005), Gorton and Souleles (2005), and Fabozzi et al. (2006)].

To analyze the motivations for using SF instruments, first and foremost it is crucial to understand why they create value. SF can create value by reducing the net costs associated with market imperfections. The literature on SF, suggests several economic motivations for originating a financing transaction under a structured model. ${ }^{18}$ First, it enables the financing of a unique asset class that $(i)$ previously may have been financed only by traditional borrowing methods; or (ii) could not be financed at all without SF. SF thus plays a critical role as a new and diverse source of funding. The second economic benefit lies in cost reduction, when the benefits of the reduced cost of funding are greater than the cost of the required credit enhancement. The third advantage refers to maintaining the sponsors' financial flexibility by creating vehicle companies (SPVs) designated to take on the initiative, helping sponsors to

\footnotetext{
${ }^{13}$ For similar viewpoint see Caselli and Gatti (2005), Davis (2005), Akbiyikli et al. (2006), Fabozzi et al. (2006), and Leland (2007).

${ }^{14}$ Securitization typically includes Asset-Backed Securities (ABS), Residential Mortgage-Backed Securities (RMBS), Commercial Mortgage-Backed Securities (CMBS), Collateralized Debt Obligations (CDOs), and AssetBacked Commercial Paper (ABCP). For further details see, e.g., Davidson et al. (2003), Roever and Fabozzi (2003), Kothari (2006), Jobst (2007), Tavakoli (2008), Krebsz (2011), Gorton and Metrick (2013), and references therein.

${ }^{15}$ For further discussion see, e.g., Brealey et al. (1996), Kleimeier and Megginson (2000), Esty (2004a, 2004b, 2007), Gatti (2005, 2008), Blanc-Brude and Strange (2007), and references therein.

${ }^{16}$ For a comprehensive account of theoretical and empirical literature on structured leasing see, among others, Slovin et al. (1990), Caselli (2005), Fabozzi et al. (2006), and Deo (2009).

${ }^{17}$ For further discussion see, e.g., Weston et al. (2001), Arzac (2005), Capizzi (2005), Kaplan and Strömberg (2009), Rosenbaum and Pearl (2009), and Guo et al. (2011).

${ }^{18}$ See, among others, Esty (2003), Caselli and Gatti (2005), DeMarzo (2005), Fender and Mitchell (2005), Akbiyikli et al. (2006), Fabozzi et al. (2006), Tavakoli (2008), and Gorton and Metrick (2013).
} 
protect their own credit standing and future access to financial markets, by improving or maintaining financial and regulatory ratios. Additionally, SF transactions allow originators or sponsors to transfer the risk of assets or liabilities and to carry out additional business without expanding their balance sheet. SF also contributes to improving operational and informational market efficiency, reducing agency costs, and reducing information asymmetries. Finally, it also allows the issuer to leverage up, compared to senior unsecured debt, and to increase tax shields/savings.

Despite the previously mentioned economic benefits for sponsors and investors, SF transactions also have disadvantages, especially when used inappropriately. SF transactions are fairly complex and involve a significant amount of cash flow evaluation, due diligence, negotiation, and legal procedures. Consequently, structuring such a deal is more costly than corporate financing. Moreover, it can be said that there is a broad consensus that securitization played an important role in the development and propagation of the 2007-2008 financial crisis. ${ }^{19}$ One can thus identify the following problems related to the use of SF transactions: (i) complexity; (ii) off-balance sheet treatment; (iii) asymmetric information problems; (iv) agency problems; (v) higher transaction costs; and ( $v i)$ wealth expropriation. ${ }^{20}$

The credit crunch triggered by the 2007-2008 financial crisis has somewhat tarnished the previously prevailing positive image of securitization, as a process to help remedy deficiencies in financial markets, arising from incomplete capital allocation. Besides the fact that AS instruments are complex vis-à-vis SDF transactions, two major problems are commonly pointed out, underlying the roots of the 2007-2008 financial crisis: (i) asymmetric information problems; and (ii) agency problems. The increased complexity of structured instruments related to securitization, such as CDOs, squared CDOs, and even more complex securities, destroyed information, thereby making asymmetric information worse in the financial system and increasing the severity of adverse selection and moral hazard problems. Additionally, the originate-to-distribute business model, which lay behind the subprime mortgage market, was subject to the principal-agent problem. Several authors argue that securitization lead to a severe principal-agent problem where the firm, who originates the assets to be ultimately sold and securitized, retains little or no interest in the pool of securitized assets. In this case, the originator does not have the same incentive to pay attention to the creditworthiness of its customers, as would be the case when the assets remain on its balance sheet. This idea is corroborated by Fabozzi and Kothari (2007) and Jobst (2006, 2009), who argue that market failures stemming from conflicts of interest in the securitization process played a major role in the 2007-2008 crisis.

\footnotetext{
${ }^{19}$ See, among others, IMF (2008), Benmelech and Dlugosz (2009), and Brunnermeier (2009).

${ }^{20}$ See, e.g., Caselli and Gatti (2005), Fabozzi et al. (2006), Gorton (2009), and Gorton and Metrick (2013).
} 


\subsubsection{The Design of Structured Finance Transactions}

A considerable number of new financial instruments are routinely brought to the market. Thus, an interesting question to ask is whether or not the design of new securities matters, and if yes, why is it? There is a broad agreement that in a complete contracting environment security design is irrelevant. Therefore, it is possible to design and write an ex-ante incentive contract to induce the agent to act in the principal's best interest. Harris and Raviv (1989) argue that security design is a tool for resolving conflict of interest between contestants for control and outside investors and for maximizing firm value. This sheds light on designing optimal securities, and on the development of SF instruments. Allen and Gale (1988) suggest that successful SF instruments allocate cash flows to the investors who value them the most, allowing securities to be held in their most efficient form. Summarizing, SF research should focus on market imperfections to understand the design of SF transactions.

Optimal contractual arrangements derived in the financial contracting literature are mechanisms used to resolve different types of conflicts of interest or asymmetric information problems that arise in agency relationships between economic agents, ${ }^{21}$ such as entrepreneurs and financiers; i.e., the research on optimal contracting allows understanding in which situations securities are optimal responses to capital market imperfections [Sannikov (2013)]. Most of the research carried out on the formal study of financial contracting has been developed along the main argument to be resolved by endogenous contract determination. From this perspective, the literature can be classified based on a relatively stable taxonomy [Allen and Winton (1995), and Harris and Raviv (1995)].

The first group of models - allocation of cash flow rights in agency conflicts - views financial contracts as mechanisms to efficiently align the interests of entrepreneurs with outside investors. In these models, insiders presumably have the ability to appropriate (at least partially) project's income, and have access to private benefits of control. Under these conditions, it has been shown that the debt contract is the only optimal contract when lenders cannot observe borrowers' income without costs. ${ }^{22}$ In this class of models, 'equity' is entirely owned by the entrepreneur (insiders), and all external financing is raised under the form of debt contracts. ${ }^{23}$ Diamond (1984), Gale and Hellwing (1985), Williamson (1986, 1987), and Boyd and Smith (1994) developed a model where costly verification of project outcomes can be done stochastically. In such a case, they showed that standard debt contracts are almost optimal contracts. Lacker (1990) generalized Diamond's model and showed that, when a borrower holds an asset with a higher marginal utility for the borrower than for the lender, a debt contract collateralized by this asset

\footnotetext{
${ }^{21}$ These include: (i) shirking; (ii) over-consumption of firm's resources; (iii) diverting cash flow; (iv) claim dilution; (v) asset substitution; (vi) adopting suboptimal investment policies; and (vii) risk shifting.

${ }^{22}$ See, e.g., Fluck (1998) and Myers (2000).

${ }^{23}$ See, e.g., Townsend (1979), Diamond (1984), Gale and Hellwig (1985), Lacker (1990), Winton (1995), and Hart and Moore (1998).
} 
(e.g., home mortgages, car loans, or loans backed by a new business' assets) is optimal. ${ }^{24}$ In Winton (1995), when the borrower can borrow from multiple investors he prefers to issue debt-like contracts with varying degrees of seniority rather than symmetric debt-like contracts - assigning different levels of seniority to different investors reduces the duplication of verification costs. Winton's model can be applied to explain some features of SF transactions. In a Leveraged Buy-Out (LBO) many classes of debt and preferred stock are typically issued, and the most junior claims are held by management and a buyout fund that monitors management closely. The second application is AS, where relatively small financial claims are pooled by an intermediary and then refinanced. In securitization, two or more tranches are issued with different degrees of seniority among investors, the originating institution typically agrees to buy the tranche's 'first loss', ${ }^{25}$ and 'credit enhancement' is often provided by a third-party who provides coverage for additional losses up to a fixed amount.

The models developed into the second set of theories are driven by adverse selection considerations - allocation of cash flow rights in adverse selection environments. At this point, securities are designed to signal borrower's private information to lenders. Among others, Allen and Gale (1992), De and Kale (1993), and Nachman and Noe (1994) show that, with adverse selection, non-contingent securities, like standard debt, are optimal contracts. An early stream of this literature is driven by the impact of market imperfections and the economic characteristics of firms concerning their choice of debt maturity. It is mainly concerned with the effects of market frictions and imperfections, such as transaction costs, taxes, and interest rate risk on firms' debt maturity decisions. When the information about the true quality of a firm's assets is asymmetrically distributed between insiders and outsiders, financing decisions at large, and short-term debt issues in particular, may be perceived by market participants as signaling firm asset quality as suggested in, e.g., Flannery (1986) and Diamond (1991). In this framework, there may be a potential advantage for short-term debt [Myers (1977)]. In 1993 Diamond developed a model in which a firm's manager can choose debt seniority, as well as maturity. It shows that ( $i$ ) short-term debt is optimal when it is senior; (ii) long-term debt is optimal when it is junior; and (iii) long-term debt is optimal when it allows the issuance of additional senior short-term debt at the interim date.

The third group relates to the role of securities in the allocation of ownership and control rights. ${ }^{26}$ If both parties in a financing arrangement could write a contract without costs, contingent upon all possible states of the world, and lawfully enforceable, then the allocation of power in such a contractual

\footnotetext{
${ }^{24}$ See, among others, Allen and Winton (1995). Hart and Moore (1995) also provide interesting results on how different levels of seniority of debt contract can mitigate agency problems.

${ }^{25}$ This means that the originator takes all credit losses up to a certain percentage of assets' value. First loss tranche is also called equity, residual or junior tranche.

${ }^{26}$ See, e.g., Grossman and Hart (1988), Harris and Raviv (1989), Zender (1991), Aghion and Bolton (1992), and Hart and Moore (1994).
} 
relationship would be irrelevant. Additionally, there would be little room for the exercise of ownership and control rights. In this case, all relevant decisions would be made ex-ante. Aghion and Bolton (1992) examine a project's long-term financing in an incomplete contracting framework [along the lines of Grossman and Hart (1986) and Hart and Moore (1990)]. An important result of their analysis concerns the implications of the standard debt contract in terms of the optimal (contingent) allocation of control rights. Aghion and Bolton (1992) and Zender (1991) show that contracts with contingent transfer of control rights may minimize inefficiencies, which provides a rationale for standard debt contracts.

In the fourth group of models, securities are designed to optimize the information that investors have - acquisition of information. ${ }^{27}$ It is widely accepted that the volume of information held by investors affects the value of a security. Thus, securities can be designed to affect the extent to which information is acquired in order to maximize value. In this line of reasoning, Boot and Thakor (1993) developed a model where a firm issues securities to investors who have to pay to become informed on the firms' value. Similarly, Diamond (1993), Winton (1995), and Glaeser and Kallal (1997) argue that the design and issuance of different classes of securities with different degrees of seniority - structuring - reduces monitoring costs. Boot and Thakor (1993) and Riddiough (1997) show that a financial institution wishing to raise funds in the presence of asymmetric information can increase revenue by pooling assets and issuing different types of securities against the pool of cash flow. DeMarzo and Duffie (1999) developed a model akin to Boot and Thakor (1993) and argue that, considering the design of asset-backed securities, the optimal tranche is the senior one and the issuer retains the first loss tranche and any unsold fraction of the senior tranche. DeMarzo (2005) extends DeMarzo and Duffie's (1999) model and concludes that pooling and tranching allow intermediaries to leverage their capital more efficiently, enhancing the returns to their private information. An extension of the Boot and Thakor (1993) model is formulated by DeMarzo and Duffie (1997) in which they analyze the effect of information acquisition on the design of securities like collateralized mortgage obligations (CMOs). They show that marginal cash flows should be allocated to one security or another rather than split between securities. In Rajan and Winton (1995), attention turns to covenants and collateral as common features of loans made by financial institutions. They investigate how loans can be structured to enhance the institutions' incentives to monitor.

The fifth category includes models representing the allocation of risk among the different kinds of investors. ${ }^{28}$ Several authors have studied this issue based on transaction costs as a source of market incompleteness. Allen and Gale (1988) developed a perfectly competitive, symmetric information model, where there are transaction costs and concluded that the price of a security is determined by the group that values it most. Pesendorfer (1995) formulated a model related to Ross (1989) and introduced financial

\footnotetext{
${ }^{27}$ See, e.g., Boot and Thakor (1993) and DeMarzo and Duffie (1997).

${ }^{28}$ See, e.g., Allen and Gale (1988, 1991, 1994), and Pesendorfer (1995).
} 
innovation. He showed that (i) innovation can improve agents' utilities by reducing costs of marketing; (ii) the level of innovation is not necessarily constrained efficiently; and (iii) innovation eliminates indeterminacy observed in other models. An approach to security design is developed by Allen and Gale (1991), who assume an environment in which the set of traded securities is endogenous and investors are permitted to undertake unlimited short sales. In this environment, and contrary to Allen and Gale (1988) where short selling is severely limited, equilibrium emerges. Allen and Gale (1988, 1991, and 1994) argue that, in AS, these restrictions can provide arbitrage value because two portfolios of securities paying the same amount may have different prices. Considering the optimal security design problem, Fulghieri and Lukin (2001) argue that in securitization the originator may prefer to issue a security with 'high information sensitivity' if he intends to maintain a residual equity position in the pool of assets. ${ }^{29}$ Using optimal risk allocation models, Benveniste and Berger (1987) and James (1988) show that securitization can improve risk sharing and increase project funding by avoiding the Myers (1977) underinvestment problem.

The literature to date does not provide much insight into the actual path of most financial innovations and SF products. Although all models yield a number of important insightful predictions, firms' financial and financing structures decisions still remain unsatisfactorily explained, mainly $(i)$ in terms of SF transactions, and (ii) with respect to the reason why firms decide to use SF instead of common debt. One possible explanation is that existing security design theories do not simultaneously and dynamically endogenize all contractual features.

\section{Data Description}

\subsection{DealScan and DCM Analytics databases}

Our sample consists of individual loans and bond offers extracted from DealScan and DCM Analytics databases, respectively. DCM Analytics database is compiled by Dealogic and offers comprehensive information of debt securities issued on the debt capital markets. DealScan database is provided by Thomson Reuters LPC, a market information provider of individual deal information on the global syndicated loan markets. We use these two databases because we require information about the pricing characteristics of SF and SDF transactions. While DCM Analytics provides information regarding $\mathrm{CB}$ - used as a proxy for SDF transactions - and AS, DealScan provides information concerning PF loans - we use AS and PF transactions as proxies for SF instruments.

We study the factors that affect the probability of a new borrower choosing between SF and SDF transactions using a large cross section of Western European loans and bonds issued between January $1^{\text {st }}$,

\footnotetext{
${ }^{29}$ In such cases, the originator signals their incentives to monitor by maintaining an equity position.
} 
2000 and December 31 $1^{\text {st }}$, 2011. Although the database extracted from DCM Analytics contains information on several types of bonds, we include only those with a deal type code of "corporate bondinvestment-grade", "corporate bond-high yield", "asset-backed security" (ABS), and "mortgage-backed security" (MBS). ${ }^{30}$ Bond tranches classified either as fixed rate bonds, with coupon rate information, or variable rate bonds, with both spread and index information were included in the data. While DealScan database contains historical information about syndicated loans and related banking instruments, we examine only loans with a deal specific purpose code of "project finance". We also require, for both databases, that the Borrower/Issuer country belongs to Western Europe and that the tranche size (in Euro millions) be available. ${ }^{31}$ After applying these screens, we are able to examine a total of 24,435 debt issues (worth Euro 6,297.8 billion). Our sample contains information on 599 AS issues (worth Euro 179.1 billion) - of which 430 issues (worth Euro 106.3 billion) have a deal type code of ABS and 169 issues (worth Euro 72.9 billion) have a deal type code of MBS -, 20,977 CB issues (worth Euro 5,786.5 billion), and 2,859 PF issues (worth Euro 332.1 billion). We refer to this as our 'full sample'.

As the unit of observation is a single issue or a single loan tranche, multiple issues from the same transaction appear as separate observations in our database. PF and AS transactions typically consist of several tranches funding the same SPV. Therefore, we focus on the transaction tranches as our basic observation.

Since we which to perform maximum likelihood estimations of our credit spread samples for our model specification, simultaneously with a probit selection equation where the probability of signing a loan or bond is a function of either micro and macro variables, we select from our full sample those issues that have complete data on credit spread. This screen has yielded a "high-information" sub-sample of 12,080 loans [worth 4,962,996 Euro millions (M€)], of which 1,090 (worth 158,487 M€) have been classified as PF loans, AS bonds represent 439 issues (worth 140,733 M€), and 10,551 are CB issues (4,663,777 M€). Additionally, the data on macroeconomic variables (e.g., level of interest rates, market volatility, slope of the Euro swap rate $)^{32}$ is obtained from DataStream. We linked the macroeconomic

\footnotetext{
${ }^{30}$ We exclude bond issues which have a deal type code of 'Medium-Term Note', 'Non-Us Agency', 'Covered Bonds', and 'Collateralized-Debt Obligation'. Perpetual bonds and bonds with additional features such as step-up, caps, or floors were also excluded from the database. Due to the important role played by CDOs in the 2007-2008 financial crisis - CDOs based on MBS linked to the subprime market were negatively affected inflicting enormous losses on investors - and as CDO issues are frequently backed by ABS and MBS, we decided to exclude CDOs from our AS dataset.

${ }^{31}$ We consider the following countries as pertaining to Western Europe: Austria; Belgium; Cyprus; Denmark; Finland; France; Germany; Greece; Iceland; Ireland; Italy; Luxemburg; the Netherlands; Norway; Portugal; Spain; Sweden; Switzerland; and the United Kingdom.

${ }^{32}$ We identified the possible variables to use as instruments for the credit spread based on the available literature [in particular, Kleimeier and Megginson (2000), Altunbas and Gadanecz (2004), Sorge and Gadanecz (2008), Vink and Thibeault (2008), Gatti el al. (2013), and Pinto et al. (2013)], and furthermore the opinions collected during verbal discussions with top investment banks confirms our choices.
} 
variables and the microeconomic information contained in the loans (DealScan) and bonds (DCM Analytics) databases on the active date (PF loans) or issue date (AS and CB issues).

\subsection{Characteristics of Structured Finance versus Straight Debt Finance}

This section provides a statistical analysis of SF (PF and AS) versus SDF (CB) lending in Western Europe. We start by comparing the distribution of loans and bonds across time, industry, and nationality of the borrower/issuer. The financial characteristics of PF loans are compared with the sample of AS bonds, as well as with our CB sample. The distribution by year of PF, AS, and CB issues is described in Table 1. Table 2 presents the industrial distribution of the PF, AS, and CB issues, while Table 3 presents the geographic distribution of the facilities in each of these three samples.

\section{**** Insert Tables 1, 2, and 3 about here ****}

Table 1 shows the evolution of PF, AS, and CB issues between 2000 and 2011. PF lending to Western Europe peaked in 2008 (by value and number), fell in 2009 and rose again in 2010. AS also peaked in 2008 and fell in 2009. After 2009, we do not have observations in our sample. This is partly explained by the European sovereign debt crisis, which has limited the increase of securitized products, but also by the fact that an increasing number of banks have underwritten their own securitization programs to use them as a guarantee for obtaining resources in the auctions of the European Central Bank (ECB), issuing the so-called Covered Bonds. These practices have partially replaced the issue of debt by banks or the interbank market itself as sources of finance. Finally, CB issues peaked in 2009 and since then have fallen.

Table 2 reveals interesting differences between PF and AS, which largely confirm the standard picture of these two types of SF transactions. Table 2 shows that AS bonds are highly concentrated in one industry, whereas the general population of PF loans reveals a far less concentrated industrial pattern. $75.1 \%$ of all AS bonds (by value) are issued by sponsors in the financial industry, while only $1.4 \%$ of PF lending goes to borrowers in this industry. PF lending is concentrated in four key industries; i.e., industrial (37.9\%), utilities (31.1\%), transportation (13.7\%), and commercial (10.6\%) industries account for $93.3 \%$ of all PF lending (value) and $93.7 \%$ of all PF loans. Similar results are presented by Kleimeier and Megginson (2000). Based on a sample of 4.956 PF loans booked on national and international markets from January $1^{\text {st }}, 1980$ through to March $23^{\text {rd }}, 1999$, they find that no less than $90.9 \%$ of all PF lending (by value) are made to borrowers in the Commercial \& Industrial, Utilities, and Transportation industries. ${ }^{33}$ These industries account for only $24.9 \%$ of the total value - and $25.9 \%$ of the number - of AS bonds. This finding is consistent with the common wisdom that PF is used primarily to fund tangible-

\footnotetext{
${ }^{33}$ Corielli et al. (2010) present similar results. Based on a sample of PF loans closed between January 1998 and May 2003 they show that the largest share of loans was awarded to electricity/power and other energy utilities (about $52 \%$ of the total value), followed by telecommunications (28\%) and transportation (14\%).
} 
asset-rich and capital intensive projects, while AS is a form of financing where monetary assets with predictable cash flows are pooled and sold to a specially created third party that has borrowed money to finance the purchase. Conversely, a number of similarities can be established between AS and CB samples. As for AS, CB are highly concentrated in the financial institutions industry $(67.2 \%$ of the total value and $80.8 \%$ of the total number). The most interesting difference can be observed in the industrial sector, which accounts for $13.2 \%$ of all corporate bond lending, almost double the fraction for AS (6.5\%) $-8.6 \%$ of the total number versus $5.5 \%$ for AS.

Table 3 also shows clear differences between the Western European countries which attract PF lending and those where AS and CB are directed. AS bonds are highly concentrated in three countries ( $89.5 \%$ by value and $77.0 \%$ of the total number of issues are made by borrowers located in U.K., Germany, and Italy), with the bulk number of issues concentrated in the U.K. (41.2\% by value and $48.7 \%$ of all AS tranches). The general population of PF loans reveals a far less concentrated geographic pattern. No less than six countries concentrate $80.6 \%$ of the total value - and no less than $85.9 \%$ of the total number - of PF loans. Closer analysis reveals a similar pattern for CB issues, with the same six countries (Germany, U.K., France, Italy, Spain, and Portugal) accounting for an identical fraction $(81.7 \%$ of the total value of $\mathrm{CB}$ versus $80.6 \%$ of all PF lending). The biggest recipient of $\mathrm{CB}$ lending is Germany. This country accounts for $24.0 \%$ of the total value of CB issues (26.4\% for AS bonds), whereas it accounts for a mere $5.8 \%$ of the value of all PF lending. Intriguingly, U.K. borrowers are less represented in the PF sub-sample than the Spanish borrowers (23.6\% by value versus $28.0 \%$ ). Considering the emphasis placed by U.K. governments on the Private Finance Initiative (PFI); i.e., on private rather than public financing of large public infrastructure projects, one would expect a greater fraction of U.K. borrowers in the total value of PF loans.

Table 4 presents basic characteristics for the full sample of PF, AS, and CB issues. Significant differences are revealed between both SF and SDF issues, as well as between the two categories of SF issues. One of the most remarkable findings is how much larger AS and CB tranches are than PF tranches. These issues have mean values of $299 \mathrm{M} €$ and $276 \mathrm{M} €$, respectively, compared with $116 \mathrm{M} €$ for PF issues. Thus, as regards tranche size, AS securities are similar to SDF securities. This can be explained by the fact that both transactions involve the offer of securities in the capital markets, while syndicated loans are the prominent form of funding for project-financed investments.

\section{**** Insert Table 4 about here $* * * *$}

According to the average maturity (years) variable, the three types of loans are substantially different financing instruments. The average maturity of PF loans, 13.6 years, is significantly lower that of the AS bonds full sample (20.9 years), but considerably longer than that of the CB full sample (5.3 years). Additionally, compared to AS and CB samples, PF loans involve more than the number of twice 
banks in the transaction. Further, AS and CB transactions are more likely to be exposed to currency risk when compared to the PF full sample.

The most remarkable similarity between SF instruments is how frequently PF loans and AS bonds are issued with guarantees (96.9\% and $100 \%$, respectively). This largely meets the standard characteristics of PF and AS. Contrary to the traditional CB, where it is the ability of the issuer to generate sufficient cash flows to repay the debt obligation that determines the risks of the transaction, in AS the source of repayments shift from the cash flows of the issuer to the cash flows generated by the securitized assets and/or a third party guarantor, in case of default. In a PF transaction, the financing is structured with as little recourse as possible to the sponsor, while at the same time providing sufficient credit support through guarantees or undertakings of a sponsor or third party, so that lenders will be satisfied with the credit risk.

Finally, AS and CB issues are frequently extended to financial institutions, with $74.1 \%$ of AS tranches and $80.8 \%$ of CB tranches issued by borrowers in this industry. As expected, only $0.43 \%$ of all PF loans are issued by sponsors in the financial institutions industry.

\section{The Financing Choice}

When comparing the values of credit spread in AS bonds, PF loans, and CB issues highinformation samples - loans and bonds that have complete data on credit spread - we conclude that PF loans are a more expensive type of financing than CB and even than AS bonds. On the contrary, average credit spreads for AS and CB issues do not differ significantly. ${ }^{34}$ Our findings diverge from those presented by Hu and Cantor (2006), Kleimeier and Megginson (2000), and Maris and Segal (2002). Hu and Cantor (2006) and Maris and Segal (2002) state that AS securities credit spreads have been higher than CB credit spreads. Kleimeier and Megginson (2000) point out that floating-rate PF loans have lower credit spreads than do most comparable non-PF loans. We also conclude that PF issues have lower credit rating and a higher number of banks involved. Our full samples also reveal that SF loans and bonds have lower loan to value ratios than SDF issues and have longer time to maturity.

These observations are ex post in nature. They do, however, lead to a question concerning the choice between SF and SDF transactions and even between PF loans and AS bonds: What factors determine the managerial choice between these financing alternatives? In order to answer this question, the effects of each of the two financing approaches on the overall cost of financing have to be clear. For example, the decision either to go with a PF transaction or with a $\mathrm{CB}$, should be based on the trade-off

\footnotetext{
${ }^{34}$ We have run $t$-tests comparing the values of each variable in AS bonds full sample with the corresponding values in the PF loan full sample; the values of each variable in AS bonds full sample with the corresponding values in the CB full sample; and the values of each variable in PF loan full sample with the corresponding values in the CB full sample. In the interest of space we do not show the results of these tests. The results are available from the authors.
} 
between the composite cost of capital of the PF and the sponsor's, and the sponsor's overall cost of capital after the CB.

We thus want to determine what affects the probability of a new borrower choosing between SF and SDF transactions. Additionally, and given the fact that the credit spread between AS bonds and PF loans is statistically and significantly different at the $5 \%$ level or higher we have also studied the probability of a new sponsor choosing to structure a new loan as a PF or AS. Similarly, and given the fact that AS bonds and CB have similar characteristics as they are both issued in capital markets, we also studied the main factors affecting the probability of a new borrower's choice between AS and CB issues.

Moreover, as described in section 3, our sample includes SF loans and bonds, as well as SDF bonds signed/issued by borrowers in Western Europe over the years 2000-2011. Given that during this period of time we experienced two crises - $(i)$ the early 2000 recession, which affected the European Union mostly during 2000 and 2001, (ii) and the 2007-2008 financial crisis and the subsequent European sovereign debt crisis which has been affecting Western European countries since 2008 - we cannot rule out that a flight to quality might have left many borrowers in these countries credit-rationed. As a result, the probability of observing SF deals with relevant pricing information (i.e., our sample selection) might not be random but rather somewhat determined by the same risk characteristics that enter our pricing regressions. Therefore, we resort to a generalized Tobit model, following Heckman (1979). We perform a maximum likelihood estimation on our credit spread samples of our model specification, simultaneously with a probit selection equation, where the probability of signing a loan or bond is a function of either micro and macro variables.

\subsection{Determinants of the Financing Choice}

As stated in the introduction, choosing between SF and SDF includes a decision related to the firm's cost of capital, because an increase in leverage increases the required cost of capital. This is the case as SF typically refers to the transfer of a subset of a company's assets (an 'activity') into a bankruptcy-remote corporation or other special purpose vehicle or entity (SPV/SPE); i.e., the assets instrumental to managing the project are separated from the remaining assets of the parties that create the vehicle. Therefore, the factors affecting the differences in credit spread for SF and SDF transactions also affect the financing choice.

The academic literature contains numerous loan pricing studies, both theoretical and empirical. Next we review the most prominent ones. Concerning PF loans, Kleimeier and Megginson (2000) find that PF loan spreads are directly related to variables such as country risk, the use of covenants in the loan contract, and project leverage. In their paper, they conclude that a third-party guarantee significantly reduces PF loan spreads, while PF loan pricing is not a positive function of maturity and loan size. Sorge and Gadanecz (2008) detect that whereas credit spreads for both investment-grade and speculative-grade 
bonds other than PF are a positive linear function of maturity, in PF loans the term structure of credit spreads is 'hump-shaped'. Blanc-Brude and Strande (2007) argue that: (i) maturity, which is a major systematic driver of the cost of debt in standard corporate finance, has a marginal effect on Public-Private Partnerships (PPPs); (ii) tranche size is not a driver in PPPs; and (iii) when risks other than systematic risks are not managed through contracts and project design, debt spreads reflect the unallocated portion of risk. Corielli et al. (2010) point out that $(i)$ effective ring fencing via nonfinancial contracts causes a drop in the credit spread charged; (ii) a project located in a country with higher rating pays lowers credit spreads; and (iii) industrial sectors do not influence the level of credit spread. Esty and Megginson (2000, 2003) show a positive relation between syndicate size (and concentration) and loan pricing. On the contrary, Kleimeier and Megginson (2000), and Sorge and Gadanecz (2008) report that the presence of larger syndicates reduces credit spreads. Finally, Gatti et al. (2013) show that certification can create economic value by reducing loan spreads.

Virtually all of the empirical studies on CB credit spreads have found credit ratings to be one of its most important determinants. Some of the more recent papers include Duffie and Singleton (1999), Collin-Dufresne et al. (2001), Elton et al. (2001), Hull et al. (2004), and Gabbi and Sironi (2005). In searching for determinants of CB credit spreads, researchers also found other factors to be important, like liquidity, systematic risk, incomplete accounting information, and taxes. An important stream of the literature analyzes the relationship between spread and maturity. Several authors [e.g., Jones et al. (1984), Sarig and Warga (1989), Duffie and Singleton (2001), and Sorge and Gadanecz (2008)] argue that on average, the term structure of credit spreads for investment grade bonds appears upward-sloping. However, the literature has been more controversial regarding the term structure of credit spreads for noninvestment grade bonds [e.g., Fons (1987), Sarig and Warga (1989), and Helwege and Turner (1999)].

Referring to AS bond credit spreads, Rothberg et al. (1989) argue that liquidity and credit risk significantly affect the pricing of pass-through securities. Maris and Segal (2002) study the determinants of credit spread on CMBS and find that ( $i$ ) default probability, (ii) tranche size, (iii) transaction size, and (iv) year influence CMBS credit spreads. Ammer and Clinton (2004) find that rating downgrades are accompanied by negative returns and widening spreads. Firla-Cuchra (2005) argues that credit rating is the most important pricing factor for this asset class at issue. This idea is corroborated by Gorton and Souleles (2005), Hu and Cantor (2006), and Vink and Thibeault (2008).

Pinto et al. (2013) analyze loan and bond pricing factors and conclude that several pricing factors apply for both SF and SDF transactions. The relevant factors found in the loan pricing analysis are: $(i)$ the tranche size, the loan to value ratio, the number of banks, and currency risk- microeconomic variables; and (ii) financial crisis and the slope of the Euro area yield curve - macroeconomic variables. 
All the aforementioned pricing factors should also be important in the financing choice. Therefore, in influencing the probability of a sponsor to choose SF over SDF, we consider the fourteen variables presented in Table 5, which gives an overview of the variables and their expected impact on the sponsor financing choice. With respect to the influence of the individual determinants, the sample characteristics presented in Table 4 convey the impression that, when compared to CB, SF tranches are on average larger for AS bonds and smaller for PF loans. On average, we expect that SF tranches are smaller than SDF tranches since tranching (issuance of multiple debt security classes) and the consequent risk dispersion is often cited as one of the major SF benefits. Also, loans exposed to currency risk are more likely to be prepared as SDF transactions. Conversely, loans with longer maturity and issued with a thirdparty guarantee are more likely to be structured as SF. Comparing PF loans with AS bonds, we expect that if a sponsor would like to obtain funding for a longer period of time, he will choose to issue securities backed by receivables, rather than structuring a PF transaction.

\section{**** Insert Table 5 about here $* * * *$}

With respect to the sector or business group, PF is most commonly used for capital-intensive ventures - such as power plants, refineries, toll roads, pipelines, telecommunications facilities, and industrial plants - with relatively transparent cash flows. Thus, we expect that borrowers belonging to industrial, utilities, and transportation industries are more likely to use PF loans. Moreover, and given the importance of the PPPs in Western Europe - PPPs reduce the need for government borrowing, shift part of the risks presented by the project to the private sector, and aim at achieving more effective management of the project -, we also expect that government and public sector entities rely on PF as an important form of allowing a project to proceed without being a direct burden on the government's budget. AS is the process whereby financial assets are pooled together, with their cash flows, and converted into negotiable securities to be placed into the market. The major issuers of AS bonds are companies belonging to commercial and financial industries, with particular emphasis on banks securitization technique allows the transformation of heterogeneous assets that are mostly not negotiable by banks into liquid and homogenous securities, suitable for trade. With respect to CB, issues are also highly concentrated in the financial industry (67.2\% of the total value and $80.8 \%$ of the total number) see Table 2. Thus, we expect that financial institutions are more likely to use AS and CB issues.

There is broad consensus that SF, more specifically AS, played an important role in the development and propagation of the 2007-2008 financial crisis. Thus, transactions developed during the crisis period are more likely to be arranged as SDF transactions. However, transactions were more likely to be structured as PF, rather than AS during that period.

The general level of interest rates (risk free rate), the slope of the Euro swap curve (a proxy of the expectations about the future evolution of interest rates), and the market volatility seem to support the use 
of SF. Finally, an improvement in credit conditions, and therefore of credit accessibility by borrowers, will increase the usage of either SF or SDF. Thus, we cannot clearly determine the impact of credit accessibility on the probability of a sponsor to choose SF over SDF.

In order to test these expected impacts, a generalized Tobit model, following Heckman (1979), has been designed. This methodology and the underlying sample for the empirical analysis are presented in the following section. Although the fourteen micro and macro independent variables are selfexplanatory, the dependent variable requires definition. The credit spread corresponds to the price for the risk associated with the financing instrument, on the basis of available information, at the time of issue. For PF loans, the credit spread represents the spread paid by the borrower over 3-month Euribor or 3month Libor. For bonds, the spread is defined as the margin yielded by the security at issue above a corresponding currency treasury benchmark with a comparable maturity. None of these measures are perfect proxies for the credit risk associated with loans and bonds. In particular, the spread over Euribor or Libor does not represent the full economic cost of credit. Loans and bonds also carry fees that can be related to creditworthiness and performance. The comparability of our pricing variables across loans and bonds is improved by making the following adjustment. While in PF loans the benchmark priced off Euribor or Libor is a three-month interbank rate, bonds typically carry a spread over a benchmark government security (e.g., German Treasury Bonds). Therefore, there is a difference between the two benchmarks represented by different credit risk levels involving unsecured short-term bank risk and a risk-free government rate. Following the approach of Thomas and Wang (2004) and Sorge and Gadanecz (2008), we adjust for the risk difference of the bond and loan benchmarks by adding to the Euribor or Libor spread of the PF loans the difference between the three-month Euro Libor and the three-month German Treasury bill at the time when the loans were granted. ${ }^{35}$

\subsection{Methodology}

In order to test the expected impact on the probability of a sponsor to choose SF over SDF, PF over AS, or AS over CB, we resort to a generalized Tobit model, following Heckman (1979). We perform maximum likelihood estimations on our credit spread samples of our model specification simultaneously with a probit selection equation, where the probability of signing a loan or bond is a function of either micro and macro variables.

We have observed credit spread when a loan is an SF loan or bond versus an SDF bond (or a PF loan versus an AS bond or an AS bond versus a CB). Then we fit a binomial probit model that predicts the loan's probability of being arranged as an SF transaction. In this circumstance, $s_{i}-$ the selection

\footnotetext{
${ }^{35}$ The average difference is 31 basis points and has a standard deviation of 44 basis points during our sample period. Additionally, as loans are priced over a three month rate while bonds tend to be priced off longer-term benchmarks, we include as additional control in our regression analysis the slope of the Euro swap curve as the difference between the 5 year Euro swap rate and the 3-month Libor at the time of the signing of the loan or issuing the bonds.
} 
indicator - is set to zero or one on the factors underlying that decision. Thus, the selection indicator which is analyzed here is of a binary format: 1 for SF (or PF or AS), 0 for SDF (or AS or CB), whether the issue is presented in the analysis or not. The Heckman selection model assumes that there exists an underlying regression relationship,

$$
y_{i}=X_{i} \beta+u
$$

The dependent variable, however, is not always observed. Rather, the dependent variable for observation $i$ is observed if

$$
s_{i}=I\left(z_{i} \gamma+v \geq 0\right)
$$

where:

$$
\begin{aligned}
& u \sim N(0, \sigma) \\
& v \sim N(0,1) \\
& \operatorname{Corr}(u, v)=\rho
\end{aligned}
$$

Equation 1 is the determination equation or outcome equation and equation 2 is the selection equation. When $\rho \neq 0$, standard regression techniques applied to the first equation yield biased results. Heckman provides consistent, asymptotically efficient estimates for all the parameters in such models. ${ }^{36}$

The $I(\cdot)$ function equals 1 if the argument is true - if the loan is an SF transaction - and zero otherwise. We observe $y_{i}$ if $s_{i}=1$. The selection function (2) contains a set of explanatory factors $Z$, which must be a superset of $X$; i.e., for us to identify the model, $Z$ should contain at least one variable that is not in the outcome equation. The error either in equation 1 and equation 2, $u$ and $v$, respectively, are assumed to have a zero-conditional mean: $E[X u]=0$ and $E[Z v]=0$.

The Heckman (1979) selection model is driven by the notion that some of the $Z$ factors for a loan are different from the factors in $X$. For example, whether a sponsor belongs or not to the financial institution industry is likely to influence whether a borrower chooses an SF transaction but might be omitted from credit spread determination equation: it appears in $Z$ but not in $X$. Other factors are likely to appear in both equations. For example, the tranche size and whether the loan is arranged during the crisis period will likely influence the borrower decision to choose an SF transaction as well as the credit spread that will be paid in that transaction.

Thus, we fit the model

$$
\begin{aligned}
& \text { Credit spread }_{i}=\beta_{0}+\beta_{1} \text { Log tranche size }_{i}+\beta_{2} \text { Log loan to value }_{i}+\beta_{3} \text { Maturity }_{i} \\
& +\beta_{4} \text { Number of banks }_{i}+\beta_{5} \text { Country risk }_{i}+\beta_{6} \text { Currency risk }_{i} \\
& +\beta_{7} \text { U.K. } \text { borrowers }_{i}+\beta_{8} \text { Crisis }_{i}+\beta_{9} \text { Risk free rate }_{i}+\beta_{10} \text { Volatility }_{i}
\end{aligned}
$$

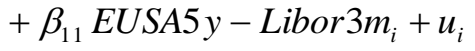

\footnotetext{
${ }^{36}$ For further analysis of Heckman selection models see, among others, Heckman (1979) and Baum (2006).
} 
and we assume that credit spread is observed if

$\gamma_{0}+\gamma_{1}$ Log tranche size $_{i}+\gamma_{2}$ Maturity $_{i}+\gamma_{3}$ Country risk $_{i}+\gamma_{4}$ Currency risk $_{i}+\gamma_{5}$ Crisis $_{i}$

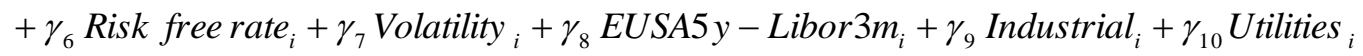

$+\gamma_{11}$ Financial int itutions $_{i}+\gamma_{12}$ Transportation $_{i}+\gamma_{13}$ Government $+\gamma_{14}$ Credit accessibility

$+v_{i}>0$

We use a full maximum-likelihood procedure to jointly estimate $\beta, \gamma$, and $\rho$. The model is fitted over the entire sample and gives an estimate of the crucial correlation $\rho$ - the correlation of $u$ and $v-$, along with a test or the hypothesis that $\rho=0$. The rejection of this hypothesis means that an OLS estimation of equation 1 will produce inconsistent estimates of $\beta$. When running our model we adjusted for heteroskedasticity using the methodology proposed by Huber (1967) and White (1980). We can thus obtain robust standard errors for our credit spread model.

The above described methodology is used to analyze a sample of 599 AS issues, 20,977 CB issues, and 2,859 PF issues. From this entire sample, we have available information on credit spread (high-information samples) for a total of 1,090 PF loans, 439 AS bonds, and 10,551 CB issues. The results of this estimation are presented in the following section.

\subsection{Results}

Results are reported in Table 6 for three models: model [1] - SF loans and bonds versus SDF bonds -, model [2] - PF loans versus AS bonds -, and model [3] - AS bonds versus SDF bonds (or CB). We identified several microeconomic and macroeconomic factors as significant determinants of choosing each of the analyzed financial instruments. The reported model chi2 test is a Wald test where all coefficients in the regression model (except the constant) are 0 . We clearly reject the null hypothesis.

\section{**** Insert Table 6 about here $* * * *$}

We start our analysis by looking at the estimation of the determination equation in model [1], in which we regress credit spread against micro and macro variables for a sample that simultaneously includes PF loans and AS bonds. The coefficients of maturity, country risk, risk free rate, volatility, and U.K. borrowers' dummy variable are statistically insignificant. The natural log of the tranche size negatively influences the credit spread. This suggests that increasing the tranche size by $100 \mathrm{M} €$ will reduce the required credit spread by 101.53 bps. Similarly, the slope of the Euro swap curve (EUSA5yLibor $3 M$ ) is significantly and negatively related to credit spread. The loan to value ratio, the number of banks, and the currency risk and crisis dummy variables are significantly and positively related with credit spread.

Comparing the results obtained in estimating the determination equation for models [2] and [3], we conclude that the regression intercepts for each type of loan issue show the highest credit spread for PF loans in Western Europe when compared to AS bonds. Additionally, the loan to value ratio behaves 
differently for PF loans than for AS bonds. Whereas spread and loan to value are significantly, positively related for PF loans, they have a significant negative relationship for AS bonds. These results are in line with the expected coefficient sign for PF and AS issues. AS bonds demonstrate a larger coefficient compared to PF loans, which means that lenders associate an increase in the loan to value ratio with a significant reduction of credit risk for these types of securities. Similarly, the variable number of banks behaves differently for PF loans as compared with AS bonds. Whereas credit spread and number of banks are significantly and positively related for PF loans, they have a significantly negative relationship for AS issues. The need for a higher number of banks in arranging a PF transaction can possibly be associated with an increase in risk and thus an extra premium is demanded. For AS issues, a larger number of banks involved is able to lower the spread once investors associate a larger number of banks with an increase in the certification of the transaction. Finally, a transaction with the issue date or active date belonging to the crisis period will have a higher average credit spread of 178.77 bps, and 113.87 bps for PF, and AS issues, respectively.

Next, we will analyze the signs and magnitude of the coefficients obtained for the explanatory factors $Z$ in our selection equations. With respect to model [1], borrowers chose an SF transaction when they seek long-term financing and when they belong to a country with higher risk. Similarly, borrowers/issuers in industrial, utilities, transportation and government increase the likelihood of an SF transaction. On the contrary, the probability of observing an SF transaction decreases with the tranche size and currency risk. Several macroeconomic factors significantly determine the selection of an SF transaction. Among these, risk free rate, volatility, the slope of the Euro swap curve (EUSA5y-Libor3M), and credit accessibility influence positively the probability of observing an SF loan or bond over an SDF bond. As expected, the 2007-2008 financial crisis decreased the probability of observing an SF loan or bond. Somewhat counter intuitively, the financial institutions' dummy variable is found to decrease the likelihood of a borrower/issuer choosing an SF transaction. However, this can be explained by the fact that from the total number of uncensored observations the major part belongs to PF loans, where financial institutions are the lenders and not the borrowers/issuers. Our findings are in line with the expected impact of micro and macro factors in the financing decision between SF and SDF - see Table 5.

Considering the choice between PF and AS, the following (macro) factors do not influence the decision: volatility, credit accessibility, and the slope of the Euro swap curve (EUSA5y-Libor3M). For these factors, the expected sign of coefficients was not possible to determine clearly. As expected, for all sector dummy variables, with the exception of the financial institutions, the coefficients are positive and significant at the 5\% level. The coefficient of the financial institutions dummy variable is negative and significant, which means that sponsors belonging to the financial institution industry are less likely to use PF loans; i.e., are more likely to use securitization as a funding instrument. The country risk rating is 
positive and significant at the 5\% level. This leads to the conclusion that a sponsor located in a risky country is more likely to be financed with a PF loan than an AS bond. The same sign can be found for the other analyzed macro variables; i.e., crisis and risk free rate. We can thus conclude that the financial crisis (as expected) led to a transfer in the form of funding based on SF transactions, increasing the use of $\mathrm{PF}$ and reducing the use of AS. The negative and significant coefficient for the currency risk dummy variable indicates that in the case of currency risk AS is preferred. Finally, sponsors prefer AS bonds for larger tranches and funding with a higher time to maturity. Again, these findings are in line with the expected impact on the choice of PF over AS.

The regression results for model [3] reveal that the tranche size and industrial, utilities, financial institutions, and transportation dummy variables do not have an influence on the financing choice between AS and CB. AS is chosen when issuers seek longer-term sources of funding, are established in riskier countries and bonds face currency risk. As expected, risk free rate, volatility, and EUSA5yLibor3M positively influence the probability of observing an AS bond versus a CB. Again, and due to the relevant role played by securitization in the development and propagation of the 2007-2008 financial crisis, the crisis dummy variable is negative and significant at the 5\% level. Finally, the unique sector with a significant impact on the probability of observing an AS instead of a CB issue is government; i.e., issuers in government industry decrease the likelihood of observing an AS transaction.

In models [1] and [3] the likelihood-ratio test for $\rho=0-$ Wald test (rho=0) - lead us to accept the hypothesis of equations (3) and (4) above being independent. On the contrary, we reject this hypothesis for model [2], pointing out the presence of selection bias. However, we have re-estimated the models controlling for this selection bias and they don't yield results fundamentally different; i.e., the sign and significance of variables remain the same.

Table 5 summarizes our findings, providing an overview of the variables, their expected impact on the financing choice, and our findings. We find, for example, that: (i) the effect of lower tranche size increases the probability of selecting an SF transaction, rather than an SDF transaction - the same takes place in the selection process between AS bonds and PF loans; (ii) borrowers chose an SF transaction when they are looking for long-term financing and when they belong to a country with higher risk; (iii) borrowers/issuers in industrial, utilities, transportation and government increase the likelihood of an SF transaction, more specifically a PF transaction, while the probability of observing an AS bond issue increases if the borrower belongs to the financial industry - the coefficient of financial institutions for model [3] is statistically insignificant because financial institutions use either AS bonds and CB to get funding in capital markets; (iv) as expected, the 2007-2008 financial crisis decreased the probability of observing an SF transaction, despite the crisis increased the probability of observing a PF loan vis-a-vis an AS bond; $(v)$ the level of the interest rates, market volatility, the slope of the Euro swap curve, and 
credit accessibility positively influence the probability of observing an SF loan or bond; (vi) market volatility, the slope of the Euro swap curve, and credit accessibility proves to be irrelevant in the process of the financing decision between PF and AS.

\subsection{Robustness Checks}

As pointed out, several authors argue that credit rating is the most important pricing factor for AS bonds at issue [e.g., Rothberg et al. (1989), Maris and Segal (2002), Firla-Cuchra (2005), Gorton and Souleles (2005), Hu and Cantor (2006), Vink and Thibeault (2008), and Pinto et al. (2013)]. Therefore, in order to ensure that our estimates are unbiased, we re-estimated model [3] by augmenting the initial specifications of the determination equation with rating variable. ${ }^{37}$ We start our analysis by looking at the estimation of the determination equation in model [4], in which we regress credit spread against micro and macro variables for a sample that includes 364 AS bonds. ${ }^{38}$ We have not re-estimated models [1] and [2] because it is difficult to obtain credit risk information for PF loans - there are only $39 \mathrm{PF}$ loans with available information on credit rating. This is because the information about the credit rating for PF loans at closing date provided by DealScan is scant when compared with the credit rating information provided by DCM Analytics database for AS and CB issues.

Table 7 shows exactly the results expected; i.e., the higher the credit risk of the issuer the higher the credit spread. Comparing the results obtained in estimating the determination equation for models [3] and [4], we conclude that the coefficients on log loan to value and on number of banks and U.K. borrowers dummy variables become insignificant, while crisis dummy variable remains significantly and positively related to credit spread. Our findings are in line with both theoretical and empirical studies, which present the excessive reliance on asset securitization credit ratings as one of the causes of the 20072008 financial crisis [e.g., Tavakoli (2008), Gennaioli et al. (2010), and Mishkin (2010)]. The increasing complexity of the securitization market and the ever growing range of products being made available to investors created challenges in terms of efficient information assembly and an excessive reliance of investors on credit ratings.

\section{**** Insert Table 7 about here $* * * *$}

The regression results for model [4] reveal that the signs and magnitude of the coefficients obtained for the explanatory factors $Z$ in our selection equation are largely consistent with the original version. Only one difference in significance of the coefficients can be pointed out: regression results for

\footnotetext{
${ }^{37}$ Our classification scheme consists of 22 rating scales for two rating agencies: Standard \& Poor's (S\&P) and Moody's. Bond ratings are based on the S\&P and Moody's bond rating at issue. If both ratings are available, the average rating is calculated and used. This classification scheme follows the approach proposed by Sorge and Gadanecz (2008) and Gatti, et al. (2013).

${ }^{38}$ When estimating model [4] variable volatility was omitted because of collinearity.
} 
model [4] reveal that volatility do not have an influence on the financing choice between AS and CB when augmenting the initial specifications of the determination equation with a credit risk measure.

The 2007-2008 financial crisis played a significant role in the failure of numerous businesses, declines in consumer wealth, and a downturn in economic activity, contributing to the European sovereign debt crisis. Since the second half of 2008 we have been observing considerable financial turmoil, a flight to quality might have left many investors and intermediaries in the Western European countries credit-rationed. Hence, SF borrowers and lenders might have also changed their attitude towards SF in terms of pricing and compensation. As an additional robustness check, we examine whether the financing choice changes across time, by considering a pre-crisis period from January $1^{\text {st }}, 2000$ through to September $14^{\text {th }}, 2008$, and a crisis period from September $15^{\text {th }}, 2008$ (Lehman Brothers' bankruptcy filing date) through to December $31^{\text {st }}, 2011$. Therefore, we have re-estimated model [1] considering these two periods. The results are reported in Table 8.

\section{**** Insert Table 8 about here $* * * *$}

Comparing the results obtained in estimating the determination equation for models [5] and [6], we find that SF tranches credit spread has increased significantly during the crisis period. The split of our SF sample has a considerable impact on the regressions intercept, causing an increase of $572.93 \mathrm{bps}$ between pre-crisis and crisis sub-samples.

Coefficient of country risk, the only statistically significant for the pre-crisis period, become, when comparing regression results for pre-crisis and crisis sub-samples, insignificant. The coefficients of the log tranche size, risk free rate and EUSA5y-Libor3M become significantly, negatively related to credit spread. Finally, variables' log loan to value, and currency risk and U.K. borrowers dummy variables become significantly, positively related to credit spread. This might be explained by a liquidity shortfall in financial markets. The critical phase of the 2007-2008 financial crisis manifested a shortage of liquidity, which was reflected in a fall in asset prices below their long run fundamental price and a deterioration in external financing conditions. For example, U.K. borrowers' dummy variable becomes significantly, positively related to SF issue credit spread during the crisis period because the resulting liquidity problems (funding liquidity and balance sheet liquidity) vehemently affected U.K. financial institutions. Additionally, the significant and negative relationship between the macroeconomic variables risk free rate and EUSA5y-Libor $3 M$ and credit spread during the crisis period is not a surprise, since from late 2009, a sovereign debt crisis developed in Europe as a result of the rising private and government debt levels around the world together with a wave of downgrading of government debt in some European states. In several countries, private debts arising from a property bubble were transferred to sovereign debt as a result of banking system bailouts and government responses to slowing economies post-bubble. 
Considering the choice between SF and SDF, the results suggest that splitting our sample in precrisis and crisis period does not bias the main conclusions of our analysis. Comparing the results obtained in estimating the selection equations for models [5] and [6] we find that the main changes are related with macroeconomic factors. Risk free rate, volatility, and EUSA5y-Libor3M positively influence the probability of observing an SF transaction in crisis period only. Finally, credit accessibility variable does not influence the likelihood of observing an SF transaction in the crisis period.

\section{Summary and Conclusions}

The paper provides interesting empirical findings for both academics and practitioners. For academics, the paper provides evidence consistent with the notion that structured finance (SF) does matter, because it affects investment incentives, deadweight financing costs, and asset cash flows. Furthermore, the paper also provides results from the empirical testing of a number of predictions based on mainstream security design models. For practitioners, the paper provides framework for understanding why SF creates value and when to choose it instead of straight debt financing because, as we argue, SF reduces financing all-in cost. In particular, our empirical results are consistent with the hypothesis that firms use SF to reduce costly agency conflicts resulting from creating asset-specific governance solutions to mitigate free cash flow problems and prevent opportunistic behavior. Moreover, any transaction which is specifically structured using an SPV and is secured by ring-fencing assets producing cash flows solely for supporting the transaction, allows the issuer to obtain better credit ratings and/or leverage than it would be possible by issuing senior secured debt, because it reduces asymmetric information problems.

We applied an organizational choice model to SF and straight debt finance (SDF) transactions to determine the factors that affect the probability of a new borrower choosing between SF and SDF transactions, and even between project finance (PF) loans and asset securitization (AS) bonds or between AS bonds and corporate bonds $(\mathrm{CB})$.

We found that: $(i)$ borrowers chose an SF transaction when they are looking for long-term financing and when they operate in a higher risk country; (ii) borrowers/issuers in industrial, utilities, transportation and government showed higher likelihood to choose SF transactions; (iii) the probability of observing an SF transaction decreased with the tranche size and currency risk; (iv) several macroeconomic factors significantly determined the selection of an SF transaction - among these, the level of interest rates, the market volatility, the slope of the Euro swap curve, and the credit accessibility

positively influenced the probability of observing an SF loan or bond over an SDF bond; and (v) the 2007-2008 financial crisis, as expected, decreased the probability of observing an SF loan or bond.

Considering the choice between PF and AS: $(i)$ the coefficients of the industrial, utilities, transportation, and government dummy variables were positive; i.e., sponsors belonging to the financial 
industry were more likely to use securitization as a funding source; (ii) a sponsor located in a country with a lower sovereign rating proved more likely to be financed with a PF loan than an AS bond; (iii) the financial crisis, as expected, led to a transfer in the form of funding based on SF transactions, increasing the use of PF and reducing the use of AS; (iv) the negative and significant coefficient for the currency risk dummy variable indicated that in the case of currency risk, AS is preferred; and (v) sponsors preferred AS bonds for larger tranches and when they sought funding with a higher time to maturity.

Finally, with respect to the choice between AS and CB, we concluded that: (i) AS was chosen when issuers are looking for longer-term sources of funding, are established in riskier countries and bonds face currency risk; (ii) the level of interest rates, the market volatility, and the slope of the Euro swap curve, as expected, influenced positively the probability of observing an AS bond versus a CB; (iii) the unique sector that had a significant impact on the probability of observing an AS instead of a CB issue, was government; and (iv) again, and due to the relevant role played by securitization in the development and propagation of the 2007-2008 financial crisis, the crisis dummy variable was significantly negative.

Our results are in line with security design literature. SF transactions or instruments, based on extensively contractual and security design, allow the reduction of the net costs associated with market imperfections, namely agency problems and asymmetric information. Accordingly to Diamond (1993), Hart and Moore (1995), Winton (1995), Glaeser and Kallal (1997), and Riddiough (1997), in AS the design and issuance of different classes of securities with different degrees of seniority - structuring reduces monitoring costs. Our results corroborate these findings, as credit spread and loan to value have a significant negative relationship for AS bonds. Similarly, structural features of PF transactions, like extensive contracting, concentrated debt and equity ownership, separate legal incorporation, and high leverage, reduce costly agency conflicts at the project level.

We also corroborate Flannery (1986) and Diamond (1991) results, as borrowers chose an SF vis$a$-vis an SDF transaction when they seek long-term financing. Thus, when the information about the true quality of a firm's assets is asymmetrically distributed between insiders and outsiders, short-term debt issues may be perceived by market participants as signaling firm asset quality and borrowers prefer SDF transactions. Referring to PF, we conclude that PF is most commonly used for capital-intensive facilities and utilities with relatively transparent cash flows, in riskier than average countries, using relatively longterm financing. Thus, our results corroborate the conclusions of Shah and Thakor (1987), Kensinger and Martin (1988), and Esty (2004a, 2004b). Riskier projects should be project-financed because PF can help to reduce underinvestment by mitigating asymmetric information problems. 


\section{Bibliography}

Aghion, P., and P. Bolton, 1992. An Incomplete Contracts Approach to Financial Contracting, Review of Economic Studies 59, 473-494.

Akbiyikli, R., D. Eaton, and A. Turner, 2006. Project Finance and the Private Finance Initiative (PFI), The Journal of Structured Finance 12, 67-75.

Alchian, A., and H. Demsetz, 1972. Production, Information Costs, and Economic Organization. American Economic Review 62, 777-795.

Allen, F., and A. Winton, 1995. Corporate Financial Structure, Incentives and Optimal Contracting, in Finance - Handbooks in Operations Research and Management Science, R. A. Jarrow, V. Maksimovic, and W. T. Ziemba eds., Vol. 9, 693-720, Elsevier.

Allen, F., and D. Gale, 1988. Optimal Security Design, Review of Financial Studies 1, 229-263.

Allen, F., and D. Gale, 1991. Arbitrage, short sales, and financial innovation, Econometrica 59, 10411068 .

Allen, F., and D. Gale, 1992. Measuring distortion and missing contingencies in optimal contracts, Economic Theory 2, 1-26.

Allen, F., and D. Gale, 1994. Financial Innovation and Risk Sharing, MIT Press: Cambridge, MA.

Altunbas, Y., and B. Gadanecz, 2004. Developing Country Economic Structure and the Pricing of Syndicated Credits, The Journal of Development Studies 40, 143-173.

Ammer, J., and N. Clinton, 2004. The Impact of Credit Rating Changes on the Pricing of Asset-Backed Securities, in Structured Credit Products: Pricing, Rating, Risk Management and Basel II, W. Perraudin (editors), Risk Books.

Arzac, Enrique, 2005. Valuation for Mergers, Buyouts, and Restructuring, Wiley Finance.

Baron, David, 1974. Default Risk, Homemade Leverage, and the Modigliani-Miller Theorem, American Economic Review 64, 176-182.

Baron, David, 1976. Default Risk and the Modigliani-Miller Theorem: A Synthesis, American Economic Review 66, 204-212.

Baum, Christopher, 2006. An Introduction to Modern Econometrics Using Stata, Texas: Stata Press.

Benmelech, E., and J. Dlugosz, 2009. The Alchemy of CDO Credit Ratings, Journal of Monetary Economics 56, 617-634.

Benveniste, L., and A. Berger, 1987. Securitisation with recourse: An instrument that offers uninsured depositors sequential claims, Journal of Banking and Finance 11, 403-424.

Blanc-Brude, F., and R. Strange, 2007. How Banks Price Loans to Public Private Partnerships: Evidence from the European Markets, Journal of Applied Corporate Finance 19, 94-106.

Bolton, P., and D. Scharfstein, 1998. Corporate Finance, the Theory of the Firm, and Organizations, Journal of Economic Perspectives 12, 95-114.

Boot, A., and A. Thakor, 1993. Security Design, Journal of Finance 48, 1349-1378.

Boyd, J., and B. Smith, 1994. How Good Are Standard Debt Contracts? Stochastic Versus Nonstochastic Monitoring in a Costly State Verification Environment, Journal of Business 67, 539-561.

Brealey, R., I. Cooper, and M. Habib, 1996. Using project finance to fund infrastructure investments, Journal of Applied Corporate Finance 9, 25-38. 
Brunnermeier, Markus, 2009. Deciphering the Liquidity and Credit Crunch 2007-2008, Journal of Economic Perspectives 23, 77-100.

Capizzi, Vincenzo, 2005. Leveraged Acquisitions: Technical and Financial Issues, in Structured Finance: Techniques, Products and Markets, Stefano Caselli and Stefano Gatti (editors), 139-181, Berlin: Springer.

Caselli, Stefano, 2005. Structured Leasing Transactions, in Structured Finance: Techniques, Products and Markets, Stefano Caselli and Stefano Gatti (editors), 96-137, Berlin: Springer.

Caselli, S., and S. Gatti, 2005. Structured Finance: Techniques, Products and Market, Springer Berlin.

Cherubini, U. and G. Della Lunga, 2007. Structured Finance, the Object Oriented Approach, Wiley Finance.

Coase, Ronald, 1937. The Nature of the Firm. Economica 4, 386-405.

Collin-Dufresne, P., R. Goldstein, and J. Martin, 2001. The Determinants of Credit Spread Changes, Journal of Finance 56, 2177-2207.

Corielli, F., S. Gatti, and A. Steffanoni, 2010. Risk Shifting through Nonfinancial Contracts: Effects on Loan Spreads and Capital Structure of Project Finance Deals, Journal of Money, Credit and Banking 42, 1295-1320.

Davidson, A., A. Sanders, L. Wolff, and A. Ching, 2003. Securitization: Structuring and Investment Analysis, Wiley Finance.

Davis, Henry, 2005. The Definition of Structured Finance: Results from a Survey, Journal of Structured Finance 11, 5-10.

De, S., and J. Kale, 1993. Contingent payments and debt contracts, Financial Management 22, 106-122.

DeMarzo, Peter, 2005. The Pooling and Tranching of Securities: A Model of Informed Intermediation, The Review of Financial Studies 18, 1-35.

DeMarzo, P., and D. Duffie, 1997. A Liquidity-Based Model of Security Design - The Unabridged Version, Graduate School of Business, Stanford University.

DeMarzo, P., and D. Duffie, 1999. A Liquidity-Based Model of Security Design, Econometrica 67, 6599.

Deo, Prakash, 2009. A Spreadsheet Model for Domestic Leveraged Leases, Journal of Structured Finance 15, 118-131.

Diamond, Douglas, 1984. Financial Intermediation and Delegated Monitoring, Review of Economic Studies 51, 393-414.

Diamond, Douglas, 1991. Debt Maturity Structure and Liquidity Risk, Quarterly Journal of Economics 106, 709-737.

Diamond, Douglas, 1993. Seniority and Maturity of Debt Contracts, Journal of Financial Economics 33, 341-368.

Duffie, D., and K. Singleton, 1999. Modeling Term Structures of Defaultable Bonds, Review of Financial Studies 12, 687-720.

Duffie, D., and K. Singleton, 2001. Credit Risk for Financial Institutions: Management and Pricing, Graduate School of Business, Stanford University.

Elton, E., M. Gruber, D. Agrawal, and C. Mann, 2001. Explaining the Rate Spread on Corporate Bonds, Journal of Finance 56, 247-277. 
Esty, Benjamin, 2003. The Economic Motivations for Using Project Finance, Boston: Harvard Business School publishing.

Esty, Benjamin, 2004a.Modern Project Finance - A Casebook, John Wiley \& Sons, Inc.

Esty, Benjamin, 2004b. Why Study Large Projects? An Introduction to Research on Project Finance, European Financial Management 10, 213-224.

Esty, Benjamin, 2007. An overview of project finance and infrastructure finance - 2006 update, Boston: Harvard Business School.

Esty, B., and W. Megginson, 2000. Syndicate Structure as a Response to Political Risk in the Project Finance Loan Market, Boston: Harvard Business School.

Esty, B., and W. Megginson, 2003. Creditor Rights, Enforcement, and Debt Ownership Structure: Evidence from the Global Syndicated Loan Market, Journal of Financial and Quantitative Analysis $38,37-59$.

Fabozzi, F., H. Davis, and M. Choudhry, 2006. Introduction to Structured Finance, Wiley Finance.

Fabozzi, F., and V. Kothari, 2007. Securitization: The Tool of Financial Transformation, Working Paper No. 7, Yale ICF.

Fender, I., and J. Mitchell, 2005. Structured Finance: Complexity, Risk and the Use of Ratings, BIS Quarterly Review, June, 67-79.

Finnerty, John, 1988. Financial Engineering in Corporate Finance: An Overview, Financial Management 17, pp. 14-33.

Firla-Cuchra, M., 2005. Explaining Launch Spreads on Structured Bonds, Working Paper, Oxford University.

Flannery, Mark, 1986. Asymmetric Information and Risky Debt Maturity Choice, Journal of Finance 41, 19-37.

Fluck, Zsusanna, 1998. Optimal Financial Contracting: Debt versus Outside Equity, Review of Financial Studies 11, 383-418.

Fons, Jerome, 1987. The Default Premium and Corporate Bond Experience, Journal of Finance 42, 8197.

Fulghieri, P., and D. Lukin, 2001. Information Production, Dilution Costs, and Optimal Security Design, Journal of Financial Economics 61, 3-42.

Gabbi, G., and A. Sironi, 2005. Which Factors Affect Corporate Bonds Pricing? Empirical Evidence from Eurobonds Primary Market Spreads, European Journal of Finance 11, 59-74.

Gale, D., and M. Hellwig, 1985. Incentive-Compatible Debt Contracts: The One-Period Problem, Review of Economic Studies 52, 647-663.

Gatti, Stefano, 2005. Project Finance, in Structured Finance: Techniques, Products and Market, Stefano Caselli and Stefano Gatti (editors), 37-93, Berlin: Springer.

Gatti, Stefano, 2008. Project Finance in Theory and Practice - Designing, Structuring, and Financing Private and Public Projects, Academic Press Advanced Finance Series.

Gatti, S., S. Kleimeier, W. Megginson, and A. Steffanoni, 2013. Arranger Certification in Project Finance, Financial Management 42, 1-40.

Gennaioli, N., A. Shleifer, and R. Vishny, 2010. Financial Innovation and Financial Fragility, Working Paper, National Bureau of Economic Research. 
Glaeser, E., and H. Kallal, 1997. Thin Markets, Asymmetric Information and Mortgage-Backed Securities, Journal of Financial Intermediation 6, 64-86.

Gorton, Gary, 2009. The Subprime Panic, European Financial Management 15, 10-46.

Gorton, G., and A. Metrick, 2013. Securitization, in Handbook of the Economics of Finance, G. Constantinides, M. Harris, and R. Stulz eds., Vol. 2A, 1-70, Elsevier.

Gorton, G., and N. Souleles, 2005. Special Purpose Vehicles and Securitization, Working paper 11190, National Bureau of Economic Research (NBER).

Grossman, S., and O. Hart, 1986. The Costs and Benefits of Ownership: A Theory of Vertical and Lateral Integration, Journal of Political Economy 94, 691-719.

Grossman, S., and O. Hart, 1988. One Share/One Vote and the Market for Corporate Control, Journal of Financial Economics 20, 175-202.

Guo, S., E. Hotchkiss, and W. Song, 2011. Do Buyouts (Still) Create Value? Journal of Finance 66, 479517.

Harris, M., and A. Raviv, 1989. The Design of Securities, Journal of Financial Economics 24, 255-288.

Harris, M., and A. Raviv, 1995. The Role of Games in Security Design, Review of Financial Studies 8, 327-367.

Hart, Oliver, 1988. Incomplete Contracts and the Theory of the Firm, Journal of Law and Organization 4, 119-139.

Hart, O., and J. Moore, 1990. Property Rights and the Nature of the Firm, Journal of Political Economy 98, 1119-1158.

Hart, O., and J. Moore, 1994. A Theory of Debt Based on the Inalienability of Human Capital, Quarterly Journal of Economics 109, 841-879.

Hart, O., and J. Moore, 1995. Debt and Seniority: An Analysis of the Role of Hard Claims in Constraining Management, American Economic Review 85, 567-585.

Hart, O., and J. Moore, 1998. Default and Renegotiation: A Dynamic Model of Debt, Quarterly Journal of Economics 113, 1-41.

Hart, O., and J. Moore, 1999. Foundations of Incomplete Contracts, Review of Economic Studies 66, 115138.

Heckman, James, 1979. Sample Selection Bias as a Specification Error, Econometrica 47, 153-161.

Hellwing, Martin, 1981. Bankruptcy, Limited Liability, and the Modigliani-Miller Theorem, American Economic Review 71, 155-170.

Helwege, J., and C. Turner, 1999. The Slope of the Credit Yield Curve for Speculative-grade Issuers, Journal of Finance 54, 1869-1884.

Hu, J., and R. Cantor, 2006. The Relationship between Issuance Spreads and Credit Performance of Structured Finance Securities, Journal of Fixed Income 16, 5-20.

Huber, Peter, 1967. The Behavior of Maximum Likelihood Estimates under Nonstandard Conditions, in Proceedings of the Fifth Berkeley Symposium on Mathematical Statistics and Probability 1, 221233, Berkeley, CA: University of California Press.

Hull, J., M. Predescu, and A. White, 2004. The Relationship between Credit Default Swap Spreads, Bond Yields, and Credit Rating Announcements, Journal of Banking and Finance 28, 2789-2811. 
IMF, 2008. The Recent Financial Turmoil - Initial Assessment, Policy Lessons, and Implications for Fund Surveillance, April, International Monetary Fund.

James, Christopher, 1988. The Use of Loan Sales and Standby Letters Of Credit by Commercial Banks, Journal of Monetary Economics 22, 395-422.

Jensen, M., and W. Meckling, 1976. Theory of the Firm: Managerial Behavior, Agency Costs, and Ownership Structure, Journal of Financial Economics 3, 305-360.

Jobst, Andreas, 2006. What is Structured Finance? The Securitization Conduit 8, 1-9.

Jobst, Andreas, 2007. A Primer on Structured Finance, Journal of Derivatives and Hedge Funds 13, 199213.

Jobst, Andreas, 2009. Islamic Securitization after the Subprime Crisis, Journal of Structured Finance 14, 41-57.

Jones, E., S. Mason, and E. Rosenfeld, 1984. Contingent Claims Analysis of Corporate Capital Structures: An Empirical Investigation, Journal of Finance 39, 611-625.

Kaplan, S., and P. Strömberg, 2009. Leveraged Buyouts and Private Equity, Journal of Economic Perspectives 23, 121-146.

Kensinger, J., and J. Martin, 1988. Project Finance: Raising Money the Old-Fashioned Way, Journal of Applied Corporate Finance 1, 69-81.

Kleimeier, S., and W. Megginson, 2000. Are Project Finance Loans Different from Other Syndicated Credits? Journal of Applied Corporate Finance 13, 75-87.

Kothari, Vinod, 2006. Securitization: The Financial Instrument of the Future, Wiley Finance.

Krebsz, Markus, 2011. Securitization and Structured Finance Post Credit Crunch: A Best Practice Deal Lifecycle Guide, Wiley Finance.

Lacker, Jeff, 1990. Collateralized Debt as the Optimal Contract, working paper, Federal Reserve Bank of Richmond.

Leland, Hayne, 2007. Financial Synergies and the Optimal Scope of the Firm: Implications for Mergers, Spinoffs, and Structured Finance, Journal of Finance 62, 765-807.

Maris, S., and W. Segal, 2002. Analysis of Yield Spreads on Commercial Mortgage-Backed Securities, Journal of Real Estate Research 23, 235-252.

Maskin, E., and J. Tirole, 1999. Unforeseen Contingencies and Incomplete Contracts, Review of Economic Studies 66, 83-114.

Merton, Robert, 1974. On the Pricing of Corporate Debt: the Risk Structure of Interest Rates. Journal of Finance 29, 449-470.

Milgrom, P., and J. Roberts, 1992. Economics, Organization and Management, Englewood Cliffs: Prentice-Hall.

Miller, Merton, 1988. The Modigliani-Miller Propositions after Thirty Years, Journal of Economic Perspectives 2, 99-120.

Mishkin, Frederic, 2010. The Economics of Money, Banking \& Financial Markets, Addison-Wesley.

Modigliani, F., and M. Miller, 1958. The Cost of Capital, Corporation Finance and the Theory of Investment, American Economic Review 48, 261-297.

Myers, Stewart, 1977. Determinants of Corporate Borrowing, Journal of Financial Economics 5, 147175. 
Myers, Stewart, 2000. Outside Equity, Journal of Finance 55, 1005-1037.

Nachman, D., and T. Noe, 1994. Optimal Design of Securities under Asymmetric Information, Review of Financial Studies 7, 1-44.

Pesendorfer, Wolfgang, 1995. Financial Innovation in a General Equilibrium Model, Journal of Economic Theory 65, 79-116.

Pinto, J., M. Marques, and W. Megginson, 2013. A Comparative Analysis of Ex Ante Credit Spreads: Structured Finance Versus Straight Debt Finance, working paper, SSRN: 2339480.

Rajan, R., and A. Winton, 1995. Covenants and Collateral as Incentives to Monitor, Journal of Finance 50, 1113-1146.

Riddiough, Timothy, 1997. Optimal Design and Governance of Asset-Backed Securities, Journal of Financial Intermediation 6, 121-152.

Roever, W., and F. Fabozzi, 2003. A Primer on Securitization, Journal of Structured and Project Finance 9, 5-20.

Rosenbaum, J., and J. Pearl, 2009. Investment Banking: Valuation, Leveraged Buyouts, and Mergers \& Acquisitions, Wiley Finance.

Ross, Stephen, 1989. Institutional Markets, Financial Marketing and Financial Innovation, Journal of Finance 44, 541-556.

Rothberg, J., F. Nothaft, and S. Gabriel, 1989. On the Determinants of Yield Spreads between Mortgage Pass-Through and Treasury Securities, Journal of Real Estate Finance and Economics 2, 301-315.

Sannikov, Yuliy, 2013. Dynamic Security Design and Corporate Financing, in Handbook of the Economics of Finance, G. Constantinides, M. Harris, and R. Stulz eds., Vol. 2A, 1-70, Elsevier.

Sarig, O., and A. Warga, 1989. Some Empirical Estimates of the Risk Structure of Interest Rates, Journal of Finance 44, 1351-1360.

Shah, S., and A. Thakor, 1987. Optimal Capital Structure and Project Financing, Journal of Economic Theory 42, 209-243.

Smith, Vernon, 1972. Default Risk, Scale, and the Homemade Leverage Theorem. American Economic Review 62, 66-76.

Sorge, M., and B. Gadanecz, 2008. The Term Structure of Credit Spreads in Project Finance, International Journal of Finance and Economics 13, 68-81.

Stiglitz, Joseph, 1969. A Re-Examination of the Modigliani-Miller Theorem, American Economic Review 59, 784-793.

Stiglitz, Joseph, 1974. On the Irrelevance of Corporate Financial Policy, American Economic Review 64, 851-866.

Stiglitz, Joseph, 1989. Mutual Funds, Capital Structure, and Economic Efficiency: Discussion, in Theory of Valuation - Frontiers of Modern Financial Theory, Vol. 1, S. Bhattacharya, G. Constantinides (editors), 342-356, Savage: Rowman \& Littlefield.

Tasca, R., and S. Zambelli, 2005. The Asset Securitization Activity in Italy: Current and Future Trends, in Structured Finance: Techniques, Products and Markets, Stefano Caselli and Stefano Gatti (editors), 5-35, Berlin: Springer.

Tavakoli, Janet, 2008. Structured Finance Collateralized \& Debt Obligations: New Developments in Cash \& Synthetic Securitization, Wiley Finance. 
Tirole, Jean, 1999. Incomplete Contracts: Where Do We Stand? Econometrica 67, 741-781.

Townsend, Robert, 1979. Optimal Contracts and Competitive Markets with Costly State Verification, Journal of Economic Theory 21, 265-293.

Thomas, H., and Z. Wang, 2004. The Integration of Bank Syndicated Loans and Junk Bond Market, Journal of Banking and Finance 28, 299-329.

Slovin, M., M. Sushka, and J. Polonchek, 1990. Corporate Sale-and-Leasebacks and Shareholder Wealth, Journal of Finance 45, 289-299.

Vink, D., and A. Thibeault, 2008. ABS, MBS, and CDO Pricing Comparisons: An Empirical Analysis, Journal of Structured Finance 14, 27-45.

Weston, J., J. Siu, and B. Johnson, 2001. Takeovers, Restructuring, \& Corporate Governance, New Jersey: Prentice-Hall, Inc.

White, Halbert, 1980. A Heteroskedasticity-consistent Covariance Matrix Estimator and a Direct Test for Heteroskedasticity, Econometrica 48, 817-830.

Williamson, Oliver, 1990. The Firm as a Nexus of Treaties: an Introduction, in The Firm as a Nexus of Treaties, M. Aoki, B. Gustafsson, and O. E. Williamson (editors), 1-25. London: Sage Publications.

Williamson, Stephen, 1986. Costly Monitoring, Financial Intermediation, and Equilibrium Credit Rationing, Journal of Monetary Economics 18, 159-179.

Williamson, Stephen, 1987. Costly Monitoring, Loan Contracts, and Equilibrium Credit Rationing, Quarterly Journal of Economics 102, 135-145.

Winton, Andrew, 1995. Costly State Verification and Multiple Investors: The Role of Seniority, Review of Financial Studies 8, 91-123.

Zender, Jaime, 1991. Optimal Financial Instruments, Journal of Finance 46, 1645-1663. 
Table 1: Distribution of the sample of PF, AS, and CB issues by year

\begin{tabular}{|c|c|c|c|c|c|c|c|c|c|}
\hline \multirow[b]{2}{*}{ Year } & \multicolumn{3}{|c|}{ Project Finance Loans } & \multicolumn{3}{|c|}{ Asset Securitization Bonds } & \multicolumn{3}{|c|}{ Corporate Bonds } \\
\hline & $\begin{array}{c}\text { Number of } \\
\text { Tranches }\end{array}$ & $\begin{array}{c}\text { Total Value } \\
\text { of Tranches } \\
\text { (Euro } \\
\text { Millions) } \\
\end{array}$ & $\begin{array}{l}\text { Percent of } \\
\text { Total Value }\end{array}$ & $\begin{array}{c}\text { Number of } \\
\text { Tranches }\end{array}$ & $\begin{array}{c}\text { Total Value } \\
\text { of Tranches } \\
\text { (Euro } \\
\text { Millions) } \\
\end{array}$ & $\begin{array}{l}\text { Percent of } \\
\text { Total Value }\end{array}$ & $\begin{array}{l}\text { Number of } \\
\text { Tranches }\end{array}$ & $\begin{array}{c}\text { Total Value } \\
\text { of Tranches } \\
\text { (Euro } \\
\text { Millions) }\end{array}$ & $\begin{array}{l}\text { Percent of } \\
\text { Total Value }\end{array}$ \\
\hline 2000 & 84 & 13,502 & 4.1 & 115 & 26,027 & 14.5 & 1,250 & 341,913 & 5.9 \\
\hline 2001 & 87 & 13,061 & 3.9 & 81 & 12,990 & 7.3 & 1,138 & 363,536 & 6.3 \\
\hline 2002 & 69 & 13,455 & 4.1 & 77 & 17,709 & 9.9 & 1,187 & 278,418 & 4.8 \\
\hline 2003 & 124 & 23,067 & 6.9 & 42 & 14,894 & 8.3 & 1,962 & 376,540 & 6.5 \\
\hline 2004 & 119 & 12,292 & 3.7 & 66 & 31,555 & 17.6 & 2,477 & 393,164 & 6.8 \\
\hline 2005 & 122 & 18,278 & 5.5 & 53 & 10,034 & 5.6 & 2,454 & 597,527 & 10.3 \\
\hline 2006 & 131 & 18,340 & 5.5 & 55 & 10,639 & 5.9 & 2,628 & 691,627 & 12.0 \\
\hline 2007 & 233 & 27,204 & 8.2 & 35 & 3,469 & 1.9 & 2,819 & 575,316 & 9.9 \\
\hline 2008 & 638 & 60,423 & 18.2 & 39 & 36,122 & 20.2 & 1,125 & 444,552 & 7.7 \\
\hline 2009 & 376 & 33,567 & 10.1 & 36 & 15,694 & 8.8 & 1,412 & 797,634 & 13.8 \\
\hline 2010 & 496 & 53,187 & 16.0 & - & - & - & 1,337 & 506,067 & 8.7 \\
\hline 2011 & 380 & 45,739 & 13.8 & - & - & - & 1,188 & 420,238 & 7.3 \\
\hline Total & 2,859 & 332,114 & 100.0 & 599 & 179,132 & 100.0 & 20,977 & $5,786,532$ & 100.0 \\
\hline
\end{tabular}

Table 2: Industrial distribution of PF, AS, and CB issues

\begin{tabular}{|c|c|c|c|c|c|c|c|c|c|}
\hline \multirow[b]{2}{*}{$\begin{array}{l}\text { Industrial Category } \\
\text { of Borrower }\end{array}$} & \multicolumn{3}{|c|}{ Project Finance Loans } & \multicolumn{3}{|c|}{ Asset Securitization Bonds } & \multicolumn{3}{|c|}{ Corporate Bonds } \\
\hline & $\begin{array}{l}\text { Number of } \\
\text { Tranches }\end{array}$ & $\begin{array}{c}\text { Total Value } \\
\text { of Tranches } \\
\text { (Euro } \\
\text { Millions) }\end{array}$ & $\begin{array}{l}\text { Percent of } \\
\text { Total Value }\end{array}$ & $\begin{array}{l}\text { Number of } \\
\text { Tranches }\end{array}$ & $\begin{array}{c}\text { Total Value } \\
\text { of Tranches } \\
\text { (Euro } \\
\text { Millions) }\end{array}$ & $\begin{array}{l}\text { Percent of } \\
\text { Total Value }\end{array}$ & $\begin{array}{l}\text { Number of } \\
\text { Tranches }\end{array}$ & $\begin{array}{l}\text { Total Value } \\
\text { of Tranches } \\
\text { (Euro } \\
\text { Millions) }\end{array}$ & $\begin{array}{l}\text { Percent of } \\
\text { Total Value }\end{array}$ \\
\hline Commercial & 454 & 35,259 & 10.6 & 90 & 21,750 & 12.1 & 1,226 & 677,251 & 11.7 \\
\hline Industrial & 836 & 125,993 & 37.9 & 33 & 11,622 & 6.5 & 1,802 & 761,763 & 13.2 \\
\hline Utilities & 1,206 & 103,214 & 31.1 & 27 & 8,522 & 4.8 & 692 & 355,409 & 6.1 \\
\hline Financial Institutions & 12 & 4,777 & 1.4 & 444 & 134,457 & 75.1 & 16,952 & $3,887,415$ & 67.2 \\
\hline Transportation & 182 & 45,533 & 13.7 & 5 & 2,782 & 1.6 & 261 & 96,199 & 1.7 \\
\hline Government & 112 & 8,518 & 2.6 & - & - & - & 7 & 794 & 0.0 \\
\hline Other & 57 & 8,819 & 2.7 & - & - & - & 37 & 7,701 & 0.1 \\
\hline Total & 2,859 & 332,114 & 100.0 & 599 & 179,132 & 100.0 & 20,977 & $5,786,532$ & 100.0 \\
\hline
\end{tabular}

Table 3: Geographic distribution of PF, AS, and CB issues

\begin{tabular}{|c|c|c|c|c|c|c|c|c|c|}
\hline \multirow[b]{2}{*}{$\begin{array}{l}\text { Geographic Location } \\
\text { of Borrower }\end{array}$} & \multicolumn{3}{|c|}{ Project Finance Loans } & \multicolumn{3}{|c|}{ Asset Securitization Bonds } & \multicolumn{3}{|c|}{ Corporate Bonds } \\
\hline & $\begin{array}{l}\text { Number of } \\
\text { Tranches }\end{array}$ & $\begin{array}{c}\text { Total Value } \\
\text { of Tranches } \\
\text { (Euro } \\
\text { Millions) }\end{array}$ & $\begin{array}{c}\text { Percent of } \\
\text { Total Value }\end{array}$ & $\begin{array}{l}\text { Number of } \\
\text { Tranches }\end{array}$ & $\begin{array}{c}\text { Total Value } \\
\text { of Tranches } \\
\text { (Euro } \\
\text { Millions) }\end{array}$ & $\begin{array}{l}\text { Percent of } \\
\text { Total Value }\end{array}$ & $\begin{array}{l}\text { Number of } \\
\text { Tranches }\end{array}$ & $\begin{array}{c}\begin{array}{c}\text { Total Value } \\
\text { of Tranches } \\
\text { (Euro } \\
\text { Millions) }\end{array} \\
\end{array}$ & $\begin{array}{l}\text { Percent of } \\
\text { Total Value }\end{array}$ \\
\hline Austria & 12 & 2,788 & 0.8 & 1 & 27 & 0.0 & 1,442 & 135,740 & 2.3 \\
\hline Belgium & 61 & 6,850 & 2.1 & 18 & 1,723 & 1.0 & 432 & 114,076 & 2.0 \\
\hline Cyprus & 7 & 244 & 0.1 & - & - & - & 15 & 4,419 & 0.1 \\
\hline Denmark & 11 & 1,307 & 0.4 & - & - & - & 24 & 5,000 & 0.1 \\
\hline Finland & 10 & 4,780 & 1.4 & - & - & - & 115 & 35,219 & 0.6 \\
\hline France & 229 & 27,340 & 8.2 & 32 & 1,526 & 0.9 & 1,843 & 855,408 & 14.8 \\
\hline Germany & 160 & 19,424 & 5.8 & 117 & 47,299 & 26.4 & 7,604 & $1,387,083$ & 24.0 \\
\hline Greece & 62 & 10,874 & 3.3 & 2 & 74 & 0.0 & 160 & 66,692 & 1.2 \\
\hline Iceland & 4 & 450 & 0.1 & - & - & - & 2 & 306 & 0.0 \\
\hline Ireland & 74 & 4,613 & 1.4 & 10 & 3,309 & 1.8 & 186 & 99,279 & 1.7 \\
\hline Italy & 348 & 28,296 & 8.5 & 52 & 39,314 & 21.9 & 1,755 & 611,264 & 10.6 \\
\hline Luxemburg & 3 & 311 & 0.1 & 3 & 173 & 0.1 & 79 & 27,127 & 0.5 \\
\hline Netherlands & 83 & 14,691 & 4.4 & 42 & 4,270 & 2.4 & 1,242 & 465,500 & 8.0 \\
\hline Norway & 29 & 4,658 & 1.4 & - & - & - & 1 & 350 & 0.0 \\
\hline Portugal & 198 & 20,993 & 6.3 & 11 & 1,391 & 0.8 & 420 & 85,015 & 1.5 \\
\hline Spain & 915 & 93,152 & 28.0 & 19 & 6,228 & 3.5 & 1,097 & 572,038 & 9.9 \\
\hline Sweden & 30 & 2,144 & 0.6 & - & - & - & 15 & 4,483 & 0.1 \\
\hline Switzerland & 17 & 10,769 & 3.2 & - & - & - & 1,709 & 103,240 & 1.8 \\
\hline United Kingdom & 606 & 78,429 & 23.6 & 292 & 73,797 & 41.2 & 2,836 & $1,214,293$ & 21.0 \\
\hline Total & 2,859 & 332,114 & 100.0 & 599 & 179,132 & 100.0 & 20,977 & $5,786,532$ & 100.0 \\
\hline
\end{tabular}


Table 4: Basic characteristics for the full sample of PF, AS, and CB issues

\begin{tabular}{|c|c|c|c|}
\hline Variable of interest & Project Finance Loans & Asset Securitization Bonds & Corporate Bonds \\
\hline Number of tranches & 2,859 & 599 & 20,977 \\
\hline Total volume, Euro millions & 332,114 & 179,132 & $5,786,532$ \\
\hline \multicolumn{4}{|l|}{ Tranche size, Euro millions } \\
\hline Average & 116 & 299 & 276 \\
\hline Minimum & 0.045 & 0.050 & 0.017 \\
\hline Maximum & 3,800 & 22,298 & 7,763 \\
\hline Average maturity, years & 13.6 & 20.9 & 5.3 \\
\hline Tranches with guarantee $(\%)$ & 96.9 & 100.0 & 2.1 \\
\hline Tranches with currency risk (\%) & 11.0 & 31.4 & 33.2 \\
\hline Tranches to U.K. borrowers (\%) & 21.2 & 48.7 & 13.5 \\
\hline Tranches to financial institutions (\%) & 0.428 & 74.1 & 80.8 \\
\hline Average number of banks & 6.9 & 2.4 & 2.9 \\
\hline
\end{tabular}

Table 5: Definition of variables, expected impact, and findings

\begin{tabular}{|c|c|c|c|c|c|c|c|}
\hline \multirow[b]{2}{*}{ Name } & \multirow[b]{2}{*}{ Description } & \multicolumn{3}{|c|}{ Expected Impact } & \multicolumn{3}{|c|}{ Findings } \\
\hline & & $\begin{array}{l}\text { SF vs } \\
\text { SDF }\end{array}$ & $\begin{array}{l}\text { PF vs } \\
\text { AS }\end{array}$ & $\begin{array}{l}\text { AS vs } \\
\text { CB }\end{array}$ & $\begin{array}{l}\text { SF vs } \\
\text { SDF }\end{array}$ & $\begin{array}{l}\text { PF vs } \\
\text { AS }\end{array}$ & $\begin{array}{l}\text { AS vs } \\
\text { CB }\end{array}$ \\
\hline \multicolumn{8}{|c|}{$\begin{array}{l}\text { Independent variables: } \\
\text { Microeconomic independent variables }\end{array}$} \\
\hline Log tranche size & $\begin{array}{l}\text { Natural log of the loan or bond tranche size. Tranche size is } \\
\text { converted into Euro millions when necessary. }\end{array}$ & - & - & + & - & - & I \\
\hline Maturity & Maturity of loan or bond, in years. & + & - & + & + & - & + \\
\hline Currency risk & $\begin{array}{l}\text { Dummy equal to } 1 \text { for loans and bonds that are } \\
\text { denominated in a currency different from the currency in } \\
\text { the borrower's home country or deal's nationality. }\end{array}$ & - & - & - & - & - & + \\
\hline Industrial & $\begin{array}{l}\text { Dummies equal to } 1 \text { if loan or bond finances a } \\
\text { borrower/issuer in the industrial sector. }\end{array}$ & + & + & - & + & + & I \\
\hline Utilities & $\begin{array}{l}\text { Dummies equal to } 1 \text { if loan or bond finances a } \\
\text { borrower/issuer in the utilities sector. }\end{array}$ & + & + & - & + & + & I \\
\hline Financial intitutions & $\begin{array}{l}\text { Dummies equal to } 1 \text { if loan or bond finances a } \\
\text { borrower/issuer in the financial institutions sector. }\end{array}$ & $?$ & - & + & - & - & I \\
\hline Transportation & $\begin{array}{l}\text { Dummies equal to } 1 \text { if loan or bond finances a } \\
\text { borrower/issuer in the transportation sector. }\end{array}$ & + & + & - & + & + & I \\
\hline Governement & $\begin{array}{l}\text { Dummies equal to } 1 \text { if loan or bond finances a } \\
\text { borrower/issuer in the government sector. }\end{array}$ & + & + & - & + & + & - \\
\hline \multicolumn{8}{|c|}{$\begin{array}{l}\text { Independent variables: } \\
\text { Macroeconomic independent variables }\end{array}$} \\
\hline Country risk & $\begin{array}{l}\text { S\&P's country credit rating at close. The rating is } \\
\text { converted as follows: } A A A=1, A A+=2 \text {, and so on until } \\
D=22 \text {. }\end{array}$ & + & + & + & + & + & + \\
\hline Crisis & $\begin{array}{l}\text { Dummy equal to } 1 \text { if the is sue date belongs to the crisis } \\
\text { period and } 0 \text { otherwise. }\end{array}$ & - & + & - & - & + & - \\
\hline Risk free rate & $\begin{array}{l}\text { The three-month German Treasury bill at the time of the } \\
\text { signing of the loan or issuing the bonds - a proxy for the } \\
\text { general level of interest rates. }\end{array}$ & + & $?$ & + & + & + & + \\
\hline Volatility & $\begin{array}{l}\text { The Chicago Board Options Exchange Volatility Index } \\
\text { (VIX). VIX reflects a market estimate of future volatility. }\end{array}$ & + & $?$ & + & + & I & + \\
\hline EUSA5y-Libor3M & $\begin{array}{l}\text { The slope of the Euro swap curve. Obtained as the } \\
\text { difference between the five-year Euro swap rate and the 3- } \\
\text { month Libor rate. }\end{array}$ & + & $?$ & + & + & I & + \\
\hline Credit accessibility & $\begin{array}{l}\text { The iTraxx Europe index. iTraxx is used as a proxy for } \\
\text { credit conditions and therefore for credit accessibility by } \\
\text { borrowers. }\end{array}$ & $?$ & $?$ & NA & + & I & NA \\
\hline
\end{tabular}

The following characters in Table 5 mean: - = negative impact on the probability of a sponsor to choose SF over SDF, PF over AS, or AS over CB $\mid+=$ positive impact on the probability of a sponsor to choose SF over SDF, PF over AS, or AS over CB $\mid \mathrm{I}=$ insignificant impact $\mid$ ? = sign cannot be determined clearly $\mid \mathrm{NA}=$ information about this variables is not available. 
Table 6: Regression analyses of the probability of observing an SF loan or bond

\begin{tabular}{|c|c|c|c|}
\hline $\begin{array}{l}\text { Dependent variable: } \\
\text { Credit spread (bps) }\end{array}$ & $\begin{array}{c}\text { Structured Finance (SF) } \\
\qquad[1]\end{array}$ & $\begin{array}{c}\text { Project Finance (PF) } \\
\qquad[2]\end{array}$ & $\begin{array}{c}\text { Asset Securitization (AS) } \\
{[3]}\end{array}$ \\
\hline \multicolumn{4}{|l|}{ Inde pendent variables: } \\
\hline Intercept & $\begin{array}{c}279.252^{* *} \\
(7.58)\end{array}$ & $\begin{array}{c}297.993^{\text {** }} \\
(9.02)\end{array}$ & $\begin{array}{r}67.357 \\
(0.26)\end{array}$ \\
\hline Log tranche size & $\begin{array}{l}-22.048^{* *} \\
(-4.82)\end{array}$ & $\begin{array}{l}-24.39^{* * *} \\
(-5.53)\end{array}$ & $\begin{array}{l}-7.035 \\
(-1.62) \\
\end{array}$ \\
\hline Log loan to value & $\begin{array}{c}21.379^{* *} \\
(4.40)\end{array}$ & $\begin{array}{c}33.6011^{* *} \\
(6.58)\end{array}$ & $\begin{array}{c}-29.327^{* *} \\
(-4.60)\end{array}$ \\
\hline Maturity & $\begin{array}{l}0.386 \\
(0.84)\end{array}$ & $\begin{array}{l}0.235 \\
(0.65)\end{array}$ & $\begin{array}{l}-0.493 \\
(-0.17)\end{array}$ \\
\hline Number of banks & $\begin{array}{l}1.404^{*} \\
(2.53)\end{array}$ & $\begin{array}{l}1.939^{\text {*** }} \\
(3.48)\end{array}$ & $\begin{array}{c}-10.369^{* *} \\
(-2.69)\end{array}$ \\
\hline Country risk & $\begin{array}{l}5.057 \\
(1.59) \\
\end{array}$ & $\begin{array}{l}9.663^{* * *} \\
(3.58)\end{array}$ & $\begin{array}{r}-11.168 \\
(-0.85) \\
\end{array}$ \\
\hline Currency risk & $\begin{array}{l}56.088^{* * *} \\
(3.51)\end{array}$ & $\begin{array}{l}49.479^{* *} \\
(2.75)\end{array}$ & $\begin{array}{r}-10.028 \\
(-0.48) \\
\end{array}$ \\
\hline U.K. borrowers & $\begin{array}{r}19.961 \\
(1.66)\end{array}$ & $\begin{array}{c}57.462 \\
(4.20)\end{array}$ & $\begin{array}{c}43.518 \text { * } \\
(2.30)\end{array}$ \\
\hline Cris is & $\begin{array}{l}192.439^{\text {** }} \\
(11.42)\end{array}$ & $\begin{array}{c}178.7722^{* *} \\
(11.91)\end{array}$ & $\begin{array}{c}113.874^{*} \\
(2.17)\end{array}$ \\
\hline Risk free rate & $\begin{array}{l}-0.099 \\
(-1.45)\end{array}$ & $\begin{array}{l}-0.1611^{* *} \\
(-2.85)\end{array}$ & $\begin{array}{l}0.164 \\
(0.96)\end{array}$ \\
\hline Volatility & $\begin{array}{r}0.036 \\
(0.08) \\
\end{array}$ & $\begin{array}{l}0.274 \\
(0.69) \\
\end{array}$ & $\begin{array}{l}2.106 \\
(1.72)\end{array}$ \\
\hline EUSA5y-Libor3M & $\begin{array}{l}-0.549^{* *} \\
(-5.17)\end{array}$ & $\begin{array}{l}-0.517^{* *} \\
(-5.87)^{2}\end{array}$ & $\begin{array}{l}-0.304 \\
(-1.08) \\
\end{array}$ \\
\hline $\begin{array}{l}\text { Dependent variable: } \\
\text { Probability of observing: }\end{array}$ & $\begin{array}{l}\text { SF loan or bond (versus SDF } \\
\text { bond) }\end{array}$ & PF loan (versus AS bond) & AS bond (versus SDF bond) \\
\hline \multicolumn{4}{|l|}{ Independent variables: } \\
\hline Log tranche size & $\begin{array}{l}-0.258^{* *} \\
(-17.00) \\
\end{array}$ & $\begin{array}{l}-0.209^{*} \\
(-2.48)\end{array}$ & $\begin{array}{l}-0.024 \\
(-1.62) \\
\end{array}$ \\
\hline Maturity & $\begin{array}{c}0.046^{* *} \\
(17.02)\end{array}$ & $\begin{array}{l}-0.046^{* *} \\
(-3.73)\end{array}$ & $\begin{array}{c}0.062^{* *} \\
(22.99)\end{array}$ \\
\hline Country risk & $\begin{array}{l}0.095^{* *} \\
(8.44)\end{array}$ & $\begin{array}{l}0.741^{\text {** }} \\
(3.14)\end{array}$ & $\begin{array}{l}0.064^{* *} \\
(3.57)\end{array}$ \\
\hline Currency risk & $\begin{array}{l}-0.451^{* *} \\
(-6.94)\end{array}$ & $\begin{array}{l}-1.134^{* *} \\
(-3.13)\end{array}$ & $\begin{array}{l}0.161 \text { ** } \\
(3.15)\end{array}$ \\
\hline Cris is & $\begin{array}{l}-0.724^{* *} \\
(-5.54)\end{array}$ & $\begin{array}{l}7.261^{\text {*** }} \\
(8.66)^{2}\end{array}$ & $\begin{array}{l}-0.499^{* *} \\
(-3.77)\end{array}$ \\
\hline Risk free rate & $\begin{array}{l}0.001^{* *} \\
(3.70)\end{array}$ & $\begin{array}{l}0.005^{*} \\
(2.12)\end{array}$ & $\begin{array}{l}0.002^{* *} \\
(7.28)\end{array}$ \\
\hline Volatility & $\begin{array}{l}0.014^{* * *} \\
(3.50)\end{array}$ & $\begin{array}{l}0.014 \\
(0.37) \\
\end{array}$ & $\begin{array}{l}0.017^{* * *} \\
(4.11)\end{array}$ \\
\hline EUSA5y-Libor3M & $\begin{array}{l}0.003^{* * *} \\
(4.48)\end{array}$ & $\begin{array}{r}-0.03 \\
(-0.62) \\
\end{array}$ & $\begin{array}{l}0.005^{\text {** }} \\
(8.96)\end{array}$ \\
\hline Industrial & $\begin{array}{l}0.445^{* * *} \\
(6.18)\end{array}$ & $\begin{array}{l}1.995^{\text {*** }} \\
(6.72)\end{array}$ & $\begin{array}{l}-0.106 \\
(-0.84) \\
\end{array}$ \\
\hline Utilities & $\begin{array}{l}0.750^{\text {*** }} \\
(9.77)\end{array}$ & $\begin{array}{l}2.208^{\text {*** }} \\
(7.39)\end{array}$ & $\begin{array}{l}-0.368 \\
(-1.78) \\
\end{array}$ \\
\hline Financial institutions & $\begin{array}{c}-1.369^{* *} \\
(-15.14)\end{array}$ & $\begin{array}{c}-10.989^{\text {** }} \\
(-7.06)\end{array}$ & $\begin{array}{l}0.018 \\
(0.15)\end{array}$ \\
\hline Transportation & $\begin{array}{l}0.485^{* * *} \\
(4.26)\end{array}$ & $\begin{array}{c}7.751^{\text {*** }} \\
(10.88)\end{array}$ & $\begin{array}{l}-0.367 \\
(-1.47) \\
\end{array}$ \\
\hline Government & $\begin{array}{l}1.311^{\text {*** }} \\
(3.24)\end{array}$ & $\begin{array}{c}5.967 \\
(19.72) \\
\end{array}$ & $\begin{array}{c}-3.4688^{\text {*** }} \\
(-18.25)\end{array}$ \\
\hline Credit accessibility & $\begin{array}{l}0.004^{* * *} \\
(3.77)\end{array}$ & $\begin{array}{l}0.014 \\
(1.44) \\
\end{array}$ & \\
\hline Number of observations & 15,255 & 1,036 & 21,416 \\
\hline Censored observations & 14,317 & 269 & 20,977 \\
\hline Uncensored observations & 938 & 767 & 439 \\
\hline Lambda & -3.424 & -14.705 & 12.377 \\
\hline Wald chi2 test PI-value & 0.000 & 0.000 & 0.000 \\
\hline Wald test $($ rho $=0)$ PI-value & 0.659 & 0.004 & 0.846 \\
\hline Log likelihood & $-7,776.081$ & $-4,735.209$ & $-4,345.866$ \\
\hline
\end{tabular}

The z-statistics reported in parentheses are based on heteroskedasticity-consistent standard errors. **, * indicate that the reported coefficient is statistically significant at the $1 \%$ and $5 \%$ level, respectively. 
Table 7: Regression analysis of the probability of observing an AS bond versus a CB: the impact of credit risk

\begin{tabular}{|c|c|c|}
\hline $\begin{array}{c}\text { Dependent variable: } \\
\text { Credit spread (bps) }\end{array}$ & $\begin{array}{c}\text { Asset Securitization (AS) } \\
{[3]}\end{array}$ & $\begin{array}{c}\text { Asset Securitization (AS) } \\
{[4]}\end{array}$ \\
\hline \multicolumn{3}{|l|}{ Independent variables: } \\
\hline Intercept & $\begin{array}{r}67.357 \\
(0.26)\end{array}$ & $\begin{array}{r}12.687 \\
(0.02)\end{array}$ \\
\hline Log tranche size & $\begin{array}{l}-7.035 \\
(-1.62)\end{array}$ & $\begin{array}{l}5.477 \\
(1.17)\end{array}$ \\
\hline Log loan to value & $\begin{array}{c}-29.327 \text { ** } \\
(-4.60)\end{array}$ & $\begin{array}{l}-6.017 \\
(-0.95)\end{array}$ \\
\hline Maturity & $\begin{array}{l}-0.493 \\
(-0.17)\end{array}$ & $\begin{array}{l}-0.183 \\
(-0.02)\end{array}$ \\
\hline Number of banks & $\begin{array}{c}-10.369 \\
(-2.69)\end{array}$ & $\begin{array}{l}-7.771 \\
(-1.83)\end{array}$ \\
\hline Country risk & $\begin{array}{r}-11.168 \\
(-0.85) \\
\end{array}$ & $\begin{array}{l}-8.875 \\
(-0.87)\end{array}$ \\
\hline Currency risk & $\begin{array}{r}-10.028 \\
(-0.48)\end{array}$ & $\begin{array}{r}31.391 \\
(0.92) \\
\end{array}$ \\
\hline U.K. borrowers & $\begin{array}{c}43.518 \text { * } \\
(2.30) \\
\end{array}$ & $\begin{array}{r}-9.841 \\
(-0.62) \\
\end{array}$ \\
\hline Cris is & $\begin{array}{c}113.874 \text { * } \\
(2.17)\end{array}$ & $\begin{array}{c}92.917 \text { * } \\
(2.04)\end{array}$ \\
\hline Risk free rate & $\begin{array}{l}0.164 \\
(0.96)\end{array}$ & $\begin{array}{l}0.090 \\
(0.21)\end{array}$ \\
\hline Volatility & $\begin{array}{l}2.106 \\
(1.72)\end{array}$ & \\
\hline EUSA5y-Libor3M & $\begin{array}{l}-0.304 \\
(-1.08)\end{array}$ & $\begin{array}{l}-0.499 \\
(-0.73)\end{array}$ \\
\hline Rating & & $\begin{array}{c}27.206 \\
(8.74)\end{array}$ \\
\hline
\end{tabular}

\section{Dependent variable:}

Probability of observing:

AS bond (versus SDF bond) AS bond (versus SDF bond)

\begin{tabular}{|c|c|c|}
\hline \multicolumn{3}{|l|}{ Independent variables: } \\
\hline Log tranche size & $\begin{array}{l}-0.024 \\
(-1.62)\end{array}$ & $\begin{array}{l}-0.011 \\
(-0.71)\end{array}$ \\
\hline Maturity & $\begin{array}{c}0.062^{* * *} \\
(22.99)\end{array}$ & $\begin{array}{c}0.060 \text { ** } \\
(18.29)\end{array}$ \\
\hline Country risk & $\begin{array}{l}0.064^{* *} \\
(3.57)\end{array}$ & $\begin{array}{l}0.044 \\
(2.08)\end{array}$ \\
\hline Currency risk & $\begin{array}{l}0.161^{\text {** }} \\
(3.15)^{4}\end{array}$ & $\begin{array}{l}0.220^{* * *} \\
(4.17)^{2}\end{array}$ \\
\hline Crisis & $\begin{array}{l}-0.499^{* *} \\
(-3.77)\end{array}$ & $\begin{array}{l}-0.703 \text { ** } \\
(-3.73)\end{array}$ \\
\hline Risk free rate & $\begin{array}{l}0.002^{\text {** }} \\
(7.28)\end{array}$ & $\begin{array}{l}0.001^{\text {*** }} \\
(3.67)\end{array}$ \\
\hline Volatility & $\begin{array}{l}0.017^{\text {*** }} \\
(4.11)\end{array}$ & $\begin{array}{c}0.016 \\
(1.61) \\
\end{array}$ \\
\hline EUSA5y-Libor3M & $\begin{array}{l}0.005^{\text {** }} \\
(8.96)\end{array}$ & $\begin{array}{l}0.004^{\text {*** }} \\
(6.96)^{2}\end{array}$ \\
\hline Industrial & $\begin{array}{l}-0.106 \\
(-0.84) \\
\end{array}$ & $\begin{array}{l}-0.074 \\
(-0.56) \\
\end{array}$ \\
\hline Utilities & $\begin{array}{l}-0.368 \\
(-1.78) \\
\end{array}$ & $\begin{array}{l}-0.211 \\
(-0.71) \\
\end{array}$ \\
\hline Financial institutions & $\begin{array}{l}0.018 \\
(0.15)\end{array}$ & $\begin{array}{l}0.099 \\
(0.76)\end{array}$ \\
\hline Transportation & $\begin{array}{l}-0.367 \\
(-1.47)\end{array}$ & $\begin{array}{l}-0.215 \\
(-0.65)\end{array}$ \\
\hline Government & $\begin{array}{c}-3.468 \text { ** } \\
(-18.25) \\
\end{array}$ & $\begin{array}{c}-3.280 \text { *** } \\
(-18.84) \\
\end{array}$ \\
\hline Number of observations & 21,416 & 21,341 \\
\hline Censored observations & 20,977 & 20,977 \\
\hline Uncensored observations & 439 & 364 \\
\hline Lambda & 12.377 & 7.537 \\
\hline Wald chi2 test PI-value & 0.000 & 0.000 \\
\hline Wald test $($ rho $=0)$ PI-value & 0.846 & 0.972 \\
\hline Log likelihood & $-4,345.866$ & $-3,577.622$ \\
\hline
\end{tabular}

The z-statistics reported in parentheses are based on heteroskedasticity-consistent standard errors. **, * indicate that the reported coefficient is statistically significant at the $1 \%$ and $5 \%$ level, respectively. 
Table 8: Regression analysis of the probability of observing an SF loan or bond: the impact of the 20072008 financial crisis

\begin{tabular}{|c|c|c|c|}
\hline Dependent variable: & Structured Finance (SF) & $\begin{array}{c}\text { Structured Finance }(\mathrm{SF}) \mid \\
\text { pre-crisis period }\end{array}$ & $\begin{array}{l}\text { Structured Finance }(\mathrm{SF}) \mid \\
\text { crisis period }\end{array}$ \\
\hline Credit spread (bps) & [1] & [5] & [6] \\
\hline \multicolumn{4}{|l|}{ Independent variables: } \\
\hline Intercept & $\begin{array}{c}279.252^{* *} \\
(7.58) \\
\end{array}$ & $\begin{array}{r}76.980 \\
(1.41) \\
\end{array}$ & $\begin{array}{l}649.905^{* *} \\
(11.84)^{*}\end{array}$ \\
\hline Log tranche size & $\begin{array}{c}-22.048^{* *} \\
(-4.82)\end{array}$ & $\begin{array}{r}-43.440 \\
(-1.92) \\
\end{array}$ & $\begin{array}{c}-17.649^{* *} \\
(-2.96)\end{array}$ \\
\hline Log loan to value & $\begin{array}{l}21.379^{* *} \\
(4.40)\end{array}$ & $\begin{array}{r}26.826 \\
(1.60)\end{array}$ & $\begin{array}{l}31.148^{* * *} \\
(5.88)\end{array}$ \\
\hline Maturity & $\begin{array}{l}0.386 \\
(0.84) \\
\end{array}$ & $\begin{array}{l}3.340 \\
(1.41) \\
\end{array}$ & $\begin{array}{l}-1.225 \\
(-1.31) \\
\end{array}$ \\
\hline Number of banks & $\begin{array}{l}1.404^{*} \\
(2.53) \\
\end{array}$ & $\begin{array}{r}4.341 \\
(1.88) \\
\end{array}$ & $\begin{array}{r}1.425 \\
(1.37) \\
\end{array}$ \\
\hline Country risk & $\begin{array}{l}5.057 \\
(1.59)\end{array}$ & $\begin{array}{l}9.704^{*} \\
(1.97)\end{array}$ & $\begin{array}{l}3.893 \\
(0.69)\end{array}$ \\
\hline Currency risk & $\begin{array}{l}56.088^{* *} \\
(3.51)\end{array}$ & $\begin{array}{l}-2.821 \\
(-0.06)\end{array}$ & $\begin{array}{l}74.230^{*} \\
(2.12)\end{array}$ \\
\hline U.K. borrowers & $\begin{array}{r}19.961 \\
(1.66)\end{array}$ & $\begin{array}{l}8.173 \\
(0.50) \\
\end{array}$ & $\begin{array}{l}50.329^{*} \\
(2.21)\end{array}$ \\
\hline Cris is & $\begin{array}{c}192.439^{* * *} \\
(11.42)\end{array}$ & & \\
\hline Risk free rate & $\begin{array}{l}-0.099 \\
(-1.45)\end{array}$ & $\begin{array}{r}-0.007 \\
(-0.05) \\
\end{array}$ & $\begin{array}{l}-0.749^{* * *} \\
(-4.67)\end{array}$ \\
\hline Volatility & $\begin{array}{l}0.036 \\
(0.08)\end{array}$ & $\begin{array}{l}5.251 \\
(1.43)\end{array}$ & $\begin{array}{l}-0.721 \\
(-1.20)\end{array}$ \\
\hline EUSA5y-Libor3M & $\begin{array}{l}-0.549^{* *} \\
(-5.17) \\
\end{array}$ & $\begin{array}{l}-0.411 \\
(-1.78) \\
\end{array}$ & $\begin{array}{l}-1.081^{* *} \\
(-5.98) \\
\end{array}$ \\
\hline $\begin{array}{l}\text { Dependent variable: } \\
\text { Probability of observing: }\end{array}$ & $\begin{array}{l}\text { SF loan or bond (versus SDF } \\
\text { bond) }\end{array}$ & $\begin{array}{l}\text { SF loan or bond (versus SDF } \\
\text { bond) }\end{array}$ & $\begin{array}{l}\text { SF loan or bond (versus SDF } \\
\text { bond) }\end{array}$ \\
\hline \multicolumn{4}{|l|}{ Inde pendent variables: } \\
\hline Log tranche size & $\begin{array}{l}-0.258^{* *} \\
(-17.00) \\
\end{array}$ & $\begin{array}{l}-0.226^{* *} \\
(-6.80) \\
\end{array}$ & $\begin{array}{l}-0.301^{* * *} \\
(-11.27) \\
\end{array}$ \\
\hline Maturity & $\begin{array}{c}0.046^{* *} \\
(17.02)\end{array}$ & $\begin{array}{l}0.053^{* *} \\
(14.38)\end{array}$ & $\begin{array}{l}0.040^{* *} \\
(9.43)\end{array}$ \\
\hline Country risk & $\begin{array}{l}0.0955^{* *} \\
(8.44)\end{array}$ & $\begin{array}{l}0.053^{* *} \\
(2.57)\end{array}$ & $\begin{array}{l}0.106^{* *} \\
(7.43)\end{array}$ \\
\hline Currency risk & $\begin{array}{l}-0.451^{* *} \\
(-6.94)\end{array}$ & $\begin{array}{l}-0.1933^{*} \\
(-2.45)\end{array}$ & $\begin{array}{l}-0.893^{* *} \\
(-8.61)\end{array}$ \\
\hline Cris is & $\begin{array}{l}-0.724^{* *} \\
(-5.54)\end{array}$ & & \\
\hline Risk free rate & $\begin{array}{l}0.001^{* * *} \\
(3.70)\end{array}$ & $\begin{array}{r}0.001 \\
(0.76) \\
\end{array}$ & $\begin{array}{l}0.002^{*} \\
(2.34)\end{array}$ \\
\hline Volatility & $\begin{array}{l}0.014^{* * *} \\
(3.50)\end{array}$ & $\begin{array}{r}0.017 \\
(1.05) \\
\end{array}$ & $\begin{array}{l}0.022^{\text {*** }} \\
(4.42)\end{array}$ \\
\hline EUSA5y-Libor3M & $\begin{array}{l}0.003^{* * *} \\
(4.48)\end{array}$ & $\begin{array}{l}0.002 \\
(1.52)\end{array}$ & $\begin{array}{l}0.004^{\text {*** }} \\
(3.24)^{4}\end{array}$ \\
\hline Industrial & $\begin{array}{l}0.445^{* *} \\
(6.18)\end{array}$ & $\begin{array}{l}0.459^{\text {*** }} \\
(2.90)\end{array}$ & $\begin{array}{l}0.394^{* * *} \\
(3.79)\end{array}$ \\
\hline Utilities & $\begin{array}{l}0.750^{* *} \\
(9.77)\end{array}$ & $\begin{array}{l}0.757^{\text {** }} \\
(3.14)\end{array}$ & $\begin{array}{l}0.621^{* *} \\
(5.95)\end{array}$ \\
\hline Financial institutions & $\begin{array}{c}-1.369 \text { ** } \\
(-15.14)\end{array}$ & $\begin{array}{l}-1.104^{* *} \\
(-7.47)\end{array}$ & $\begin{array}{l}-1.539^{* *} \\
(-9.77)\end{array}$ \\
\hline Transportation & $\begin{array}{l}0.485^{* *} \\
(4.26)\end{array}$ & $\begin{array}{l}0.509^{*} \\
(2.52)\end{array}$ & $\begin{array}{l}0.381^{*} \\
(2.28)\end{array}$ \\
\hline Government & $\begin{array}{l}1.311^{* * *} \\
(3.24)\end{array}$ & $\begin{array}{l}1.202^{*} \\
(2.20)\end{array}$ & $\begin{array}{l}1.437^{\text {*** }} \\
(2.56)\end{array}$ \\
\hline Credit accessibility & $\begin{array}{l}0.004^{\text {*** }} \\
(3.77)\end{array}$ & $\begin{array}{l}0.006^{*} \\
(2.10) \\
\end{array}$ & $\begin{array}{l}-0.001 \\
(-0.13) \\
\end{array}$ \\
\hline Number of observations & 15,255 & 10,585 & 4,670 \\
\hline Censored observations & 14,317 & 10,013 & 4,304 \\
\hline Uncensored observations & 938 & 572 & 366 \\
\hline Lambda & -3.424 & 91.093 & -26.223 \\
\hline Wald chi 2 test PI-value & 0.000 & 0.000 & 0.000 \\
\hline Wald test $($ rho $=0)$ PI-value & 0.659 & 0.167 & 0.067 \\
\hline Log likelihood & $-7,776.081$ & $-4,659.777$ & $-3,040.970$ \\
\hline
\end{tabular}

The $\mathrm{z}$-statistics reported in parentheses are based on heteroskedasticity-consistent standard errors. $* *, *$ indicate that the reported coefficient is statistically significant at the $1 \%$ and $5 \%$ level, respectively. 